\title{
التفسير المقاصدي للقرآن الكريم
}

\section{علي محمد أسعد}

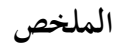 \\ يهدف البحث إلى بناء البحاه مقاصدي في التفسير، يقوم على التأصيل له بييان أهم ركائزه من مقاصد القرآن

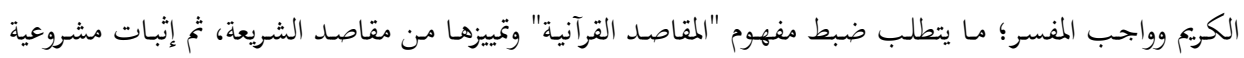

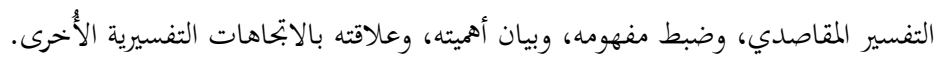 \\ الكلمات المفتاحية: مقاصد القرآن، التفسير المقاصدي، استنباط المقاصد القرآنية، أنواع المقاصد القرآنية.
}

\section{Intents-Based (Maqasidi) Interpretation of the Gracious Qur'an}

\section{Ali Muhammad As'ad}

\begin{abstract}
The purpose of this study is to build an approach of the Gracious Qur'an interpretation based on 'Maqasid or its main intents. The pillars of such an approach are based on the intents and purposes of the Qur'an and the duty of the interpreter. This requires that the concept of the Qur'anic intents be understood clearly and distinguished from the intents of the Shari'a, and then to establish the legitimacy of the intents-based interpretation of the Qur'an, to understand its concept, and to clarify its importance and its relationship with other trends of Qur'an interpretation.
\end{abstract}

Keywords: Qur'an intents (Maqasid), Intents based interpretation, the deduction of Qur'an intents, types of Qur'an intents.

$$
\text { * دكتوراه في العلوم الإسلامية، جامعة الزيتونة- تونس، أستاذ مشارك في جامعة العلوم الإسلامية العالمية- الأردن. }
$$




\section{مقدمة:}

إن التغـيرات الفكريـة والاجتماعيـة والسياسـية -بمـا أحدثتهـ مـن تسـاؤلات، وأزمـات

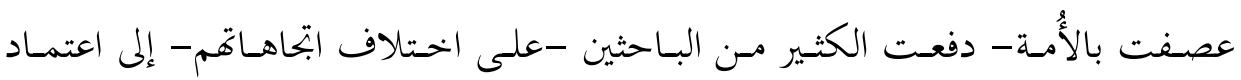

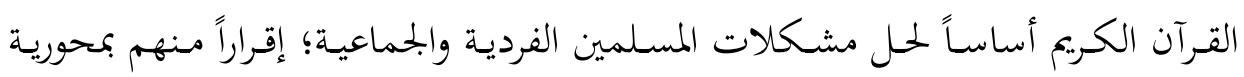

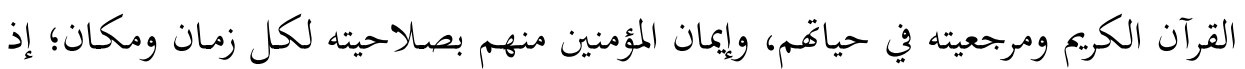
لا تنقضي عجائبه، ولا يَخَلَق على كثرة الرد. فكان لا بُسَّ مـن إعـادة فاعلية القرآن في حياتهم بتفسيره لهم، وتنزيله على واقعهم

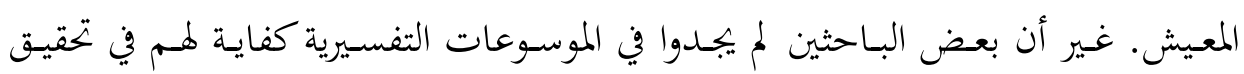
ذلك، وإن كان لا يستغنى عنها بوصفها دعائم أساسية، فتعالت دعواتم إلى التجديد في التفسير. ومن هذه الدعوات بناء ابتحاه مقاصدي قي التفسير، يقوم على الكشف عمَّا نزل به القرآن الكريم من مقاصد عامة وخاصة، كلية وجزئية، عالية وقريبة، ومحاولة ترتيبها

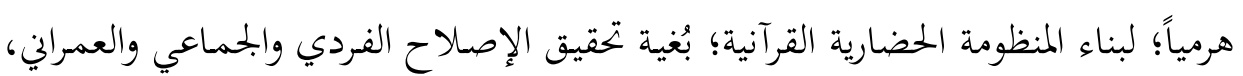
وبيان المصالح التي جاء بها القرآن الكريم، ومنهجه في معالجة القضايا الإنسانية، وهدايته إلى ما فيه الخير والفضيلة والسعادة في الدنيا والآخرة.

وقد أدَّى ذلك إلى تسرُّع بعض الدارسين في تصنيف المقاصد وترتيبها، من دون أن

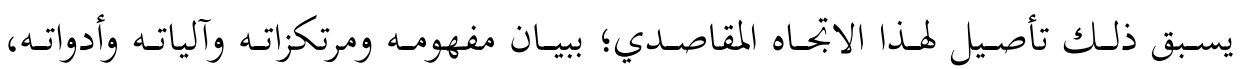
فاضطربت أقوالهم، واختلفت معايير تصنيفهم للمقاصد القرآنية. وعلى هذا، فقد رام هذا البحث أن ينحو نحو التأصيل لتفسير مقاصدي يقوم على بتحاوز الأزمة المعرفية للتفسير ولتيك

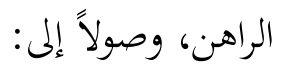

- بيان مفهوم المقاصد القرآنية وعلاقتها بمقاصد الشريعة. - بيان مفهوم التفسير المقاصدي. - إثبات مشروعية التفسير المقاصدي. - بيان علاقة التفسير المقاصدي بالمناهج والاتجاهات التفسيرية الأُخرى. 


\section{أولاً: مفهوم المقاصد القرآنية وتصنيفها}

لمَّا كان الموضوع الرئيس للبحث هو التفسير المقاصدي للقرآن الكريم، الذي يمثل

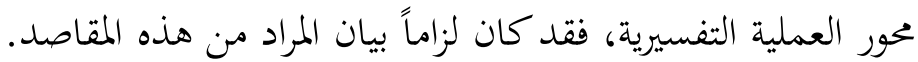

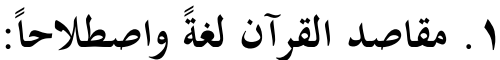

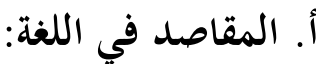

المقاصد جمع مقصد، والمقصد مصدر ميمي مأخوذ من الفعل قصد، ' قصد قصداً

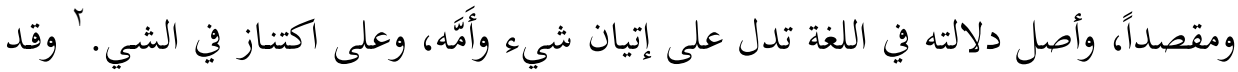

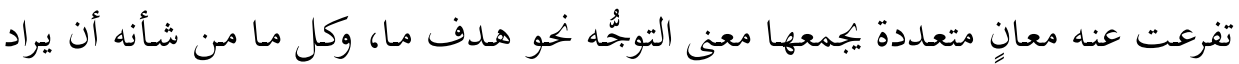
ويقصد ويُعقّق المراد، ويظهر ذلك في المعاني الآتية:

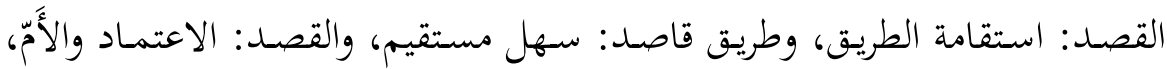

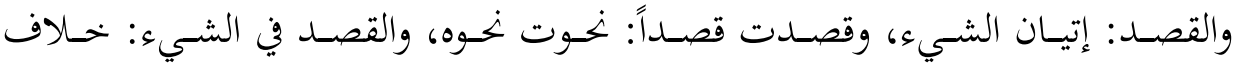

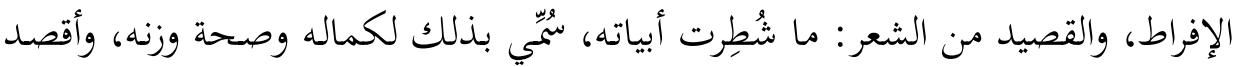

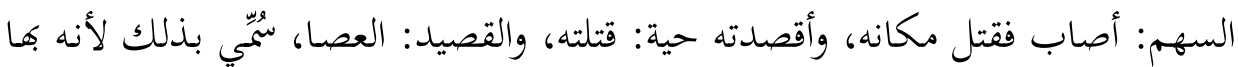

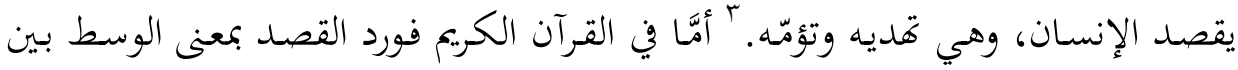
مقصد على وزن مفعل، وهذا الوزن يُستخدَم في زمان القصد، أو في المكان المقصود فيه، أو المرجع [القصد])، ومن

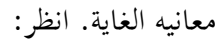
- الفيومي، أممد بن حمده المقري. المصباح المنير في غريب الشرح الكبير للرافعي، بيروت: دار الكتب

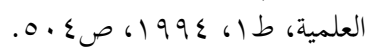
- جماعة من كبار اللغويين. المعجم العربي الأساسي، لاروس: المنظمة العربية للتربية والثقافة والعلوم، ه9 (9) مه،

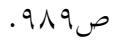

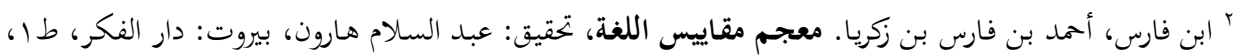

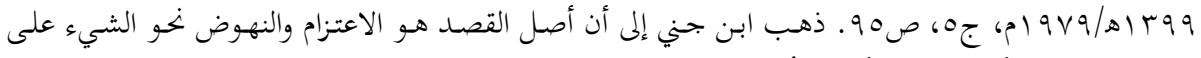

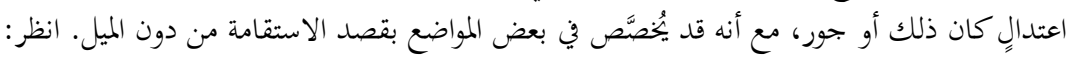

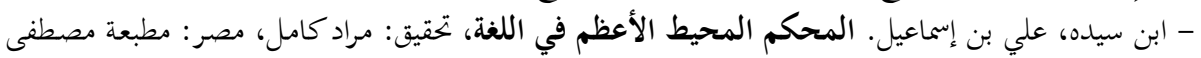

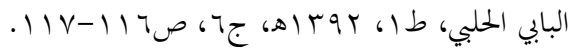

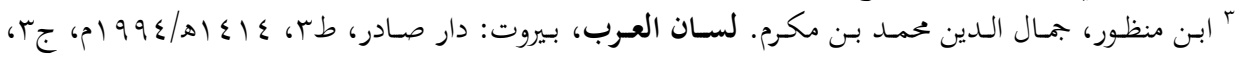




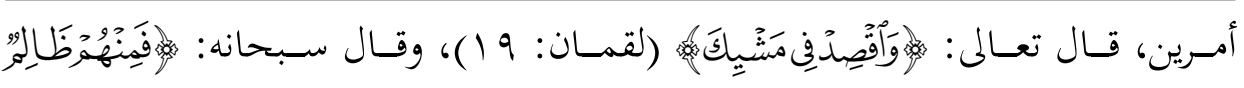

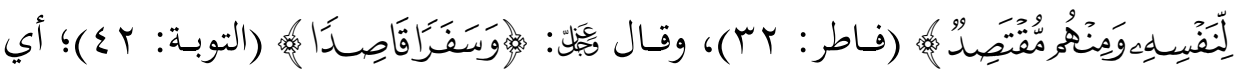

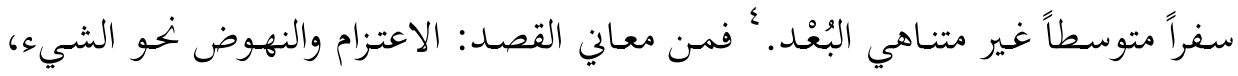
والمقصد: الغاية.

\section{ب. تعريف مقاصد القرآن اصطلاحاً وعلاقتها بمقاصد الشريعة:}

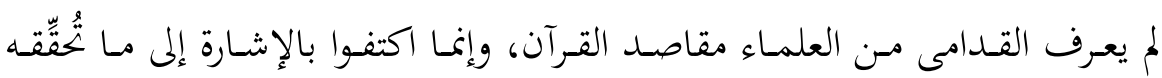

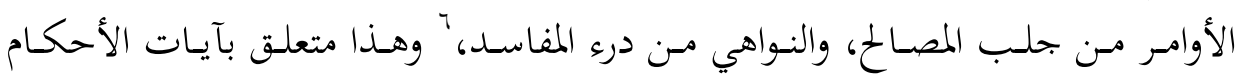

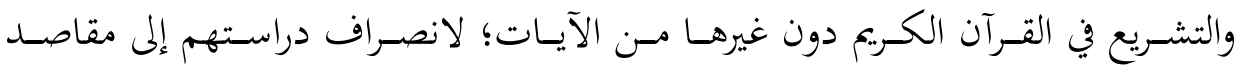

\section{أنظ}

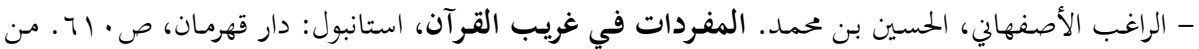

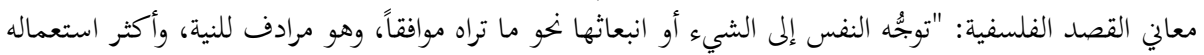

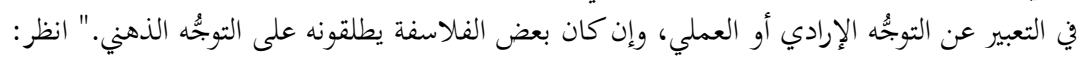

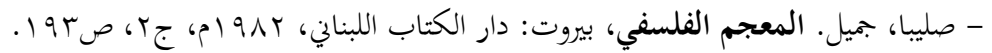

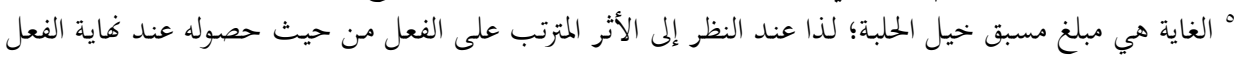

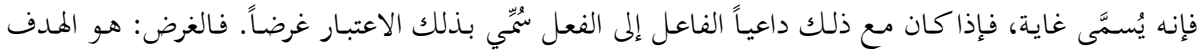

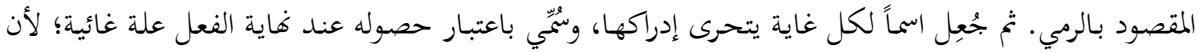

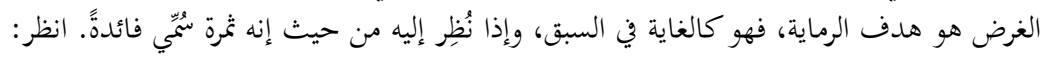

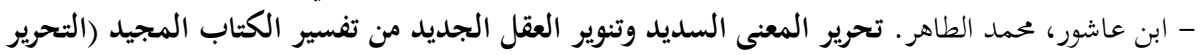

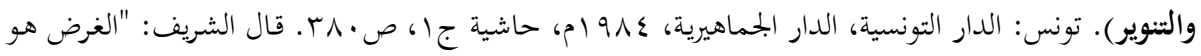

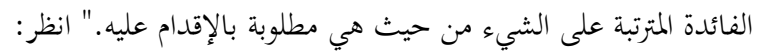

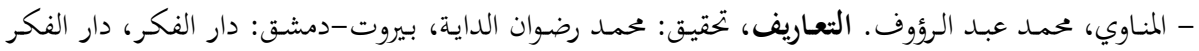

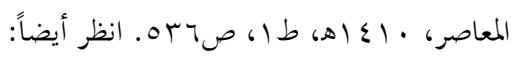

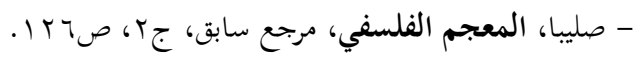

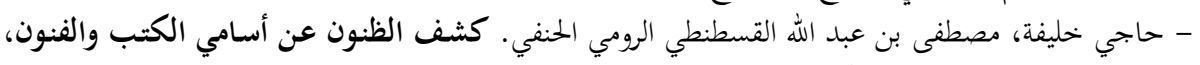

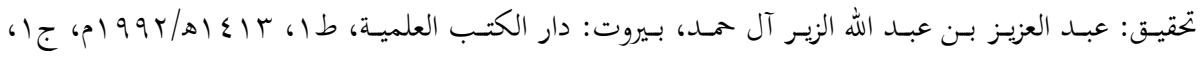

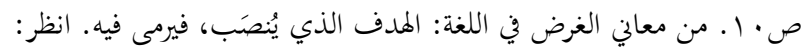

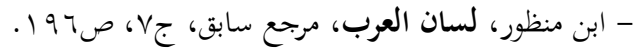

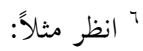

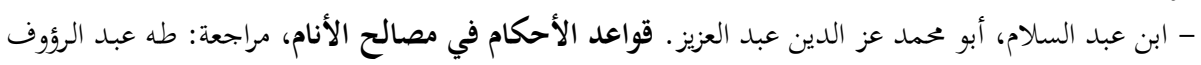

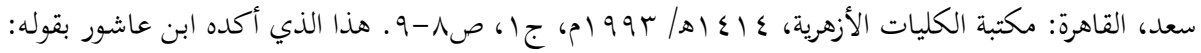

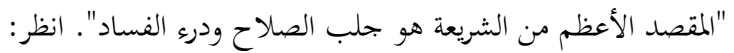

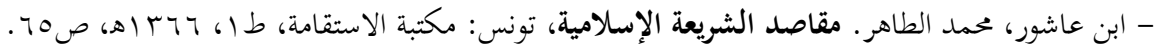


الشـريعة. فالتشريع مـا هو إلا موضسوع مـن الموضوعات القرآنية، وقـد عرَّف ابن عاشـور

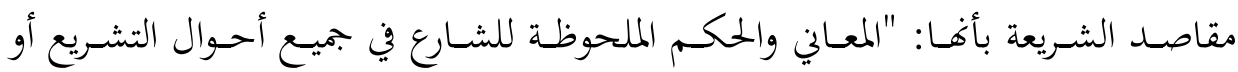
معظمها، بحيث لا تختص ملاحظتها في نوع خحاص من أحكام الشريعة. فيدخل في هذا

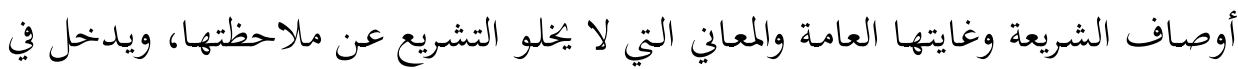

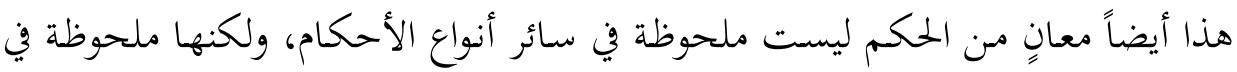

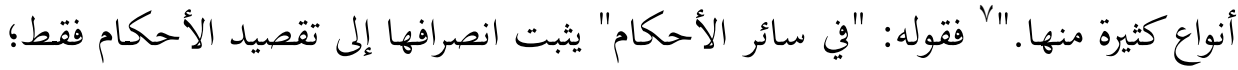

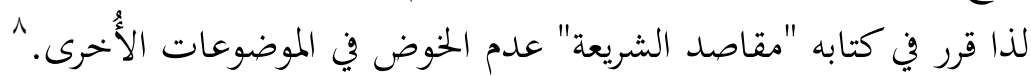

فالعلاقة بين مقاصد القرآن الكريم ومقاصد الشريعة "هي عموم وخصوص وجهي،

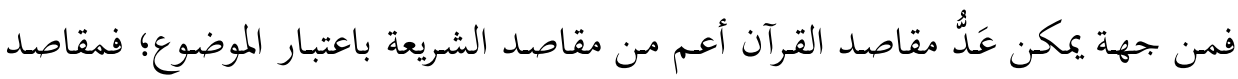

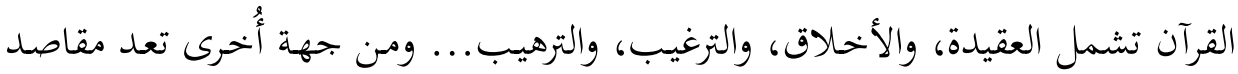

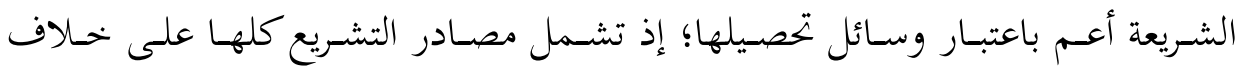
وسائل تحصيل مقاصد القرآن."

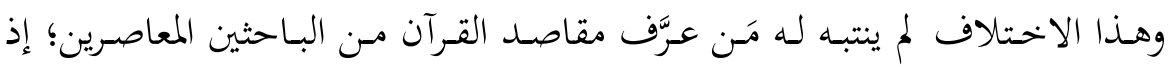

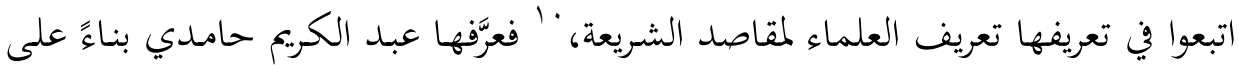

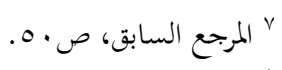

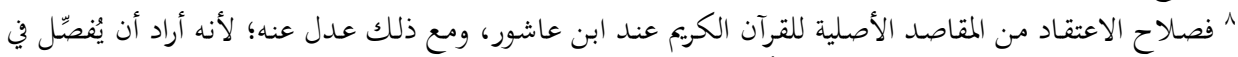

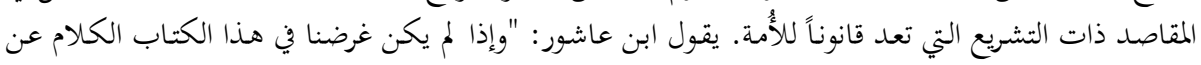

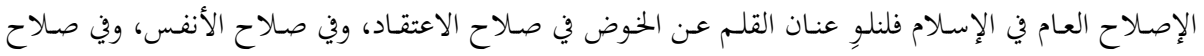

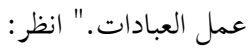

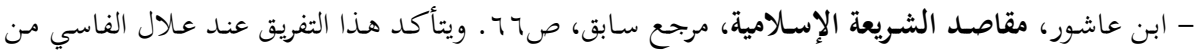

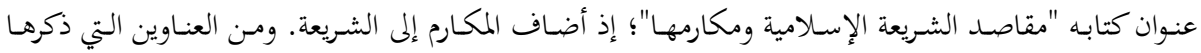

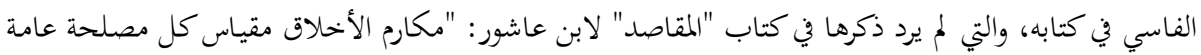

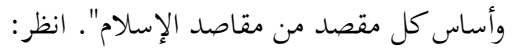

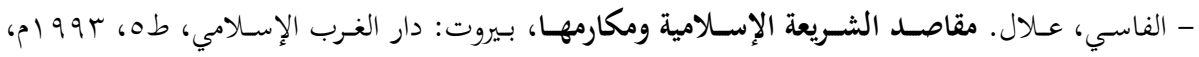
صبا 19 وما بعدها.

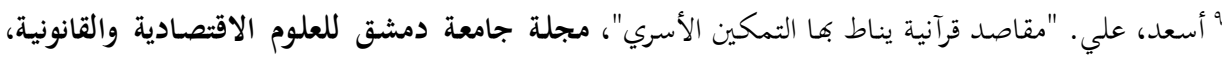

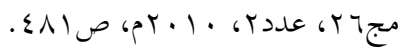

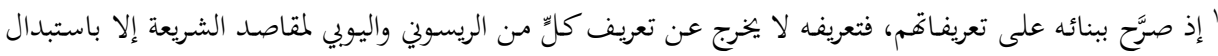

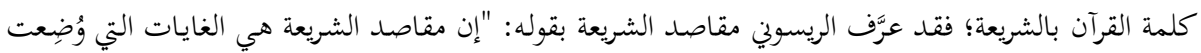

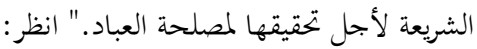


ما ذكره العلماء من تعريفات لمقاصد الشريعة بقوله: "مقاصد القرآن: هي الغايات التي

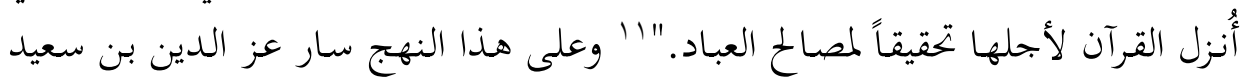

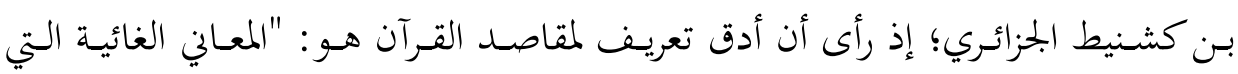

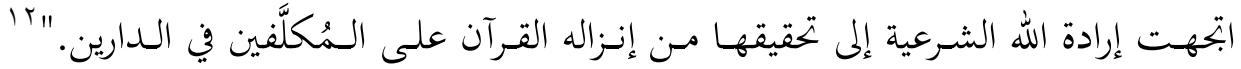

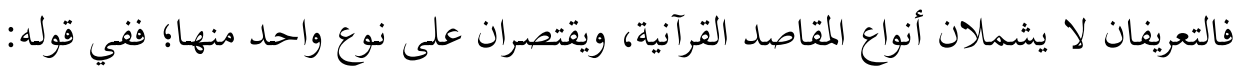

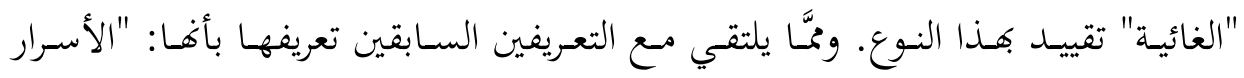

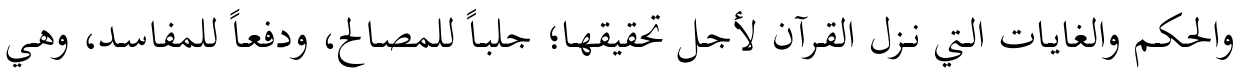

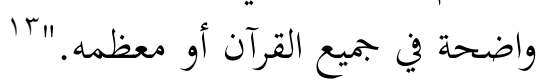

وأمَّا مسعود بودوخحة فعرَّف مقاصد القرآن بأفها: "القضايا الأساسية والمحاور الكبرى

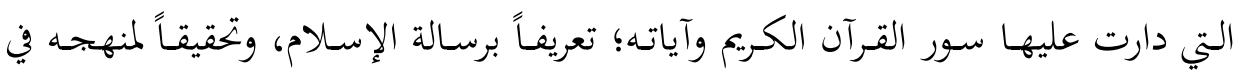

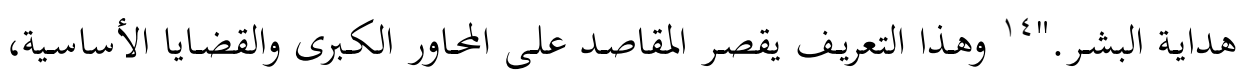

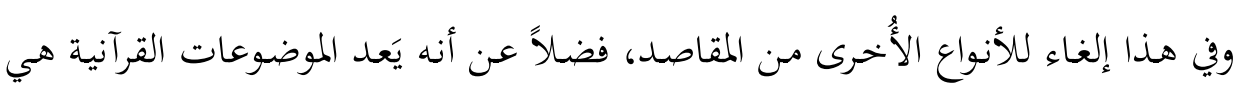

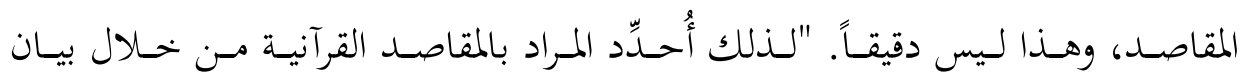
مستويات الخطاب القرآي، والتي يمكن حصرها بثلاثة مستويات:

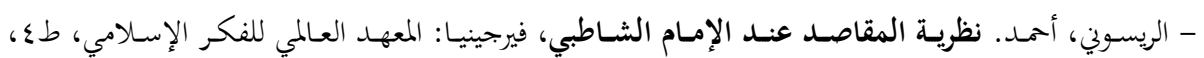

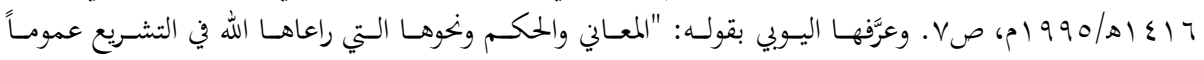

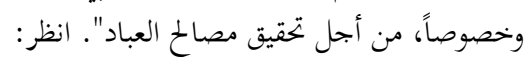

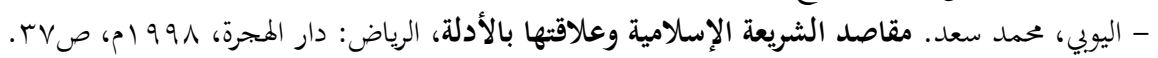

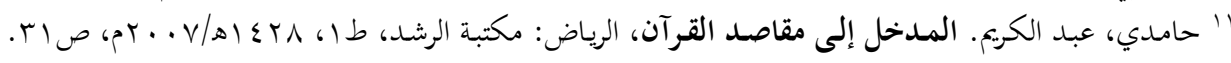

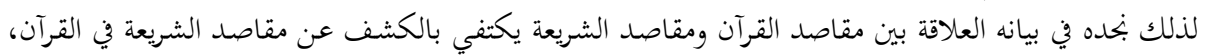
وإثبات أنه أصل لها.

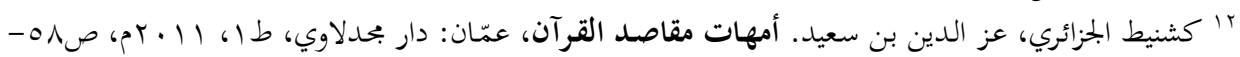

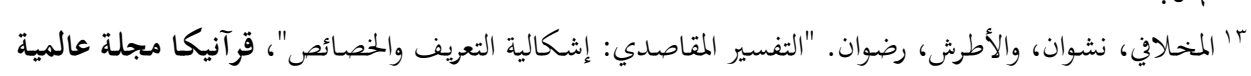

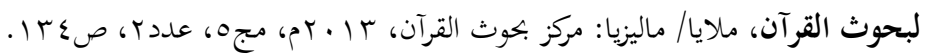

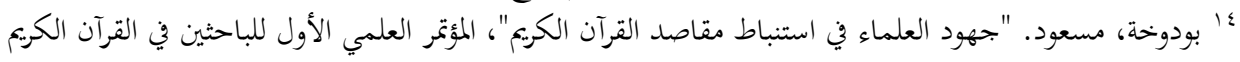

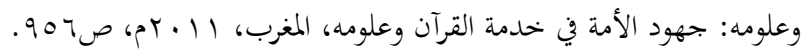


المستوى الأول: ما جاء به القرآن الكريم من مضامين؛ سواء أكانت خبراً أم إنشاءً،

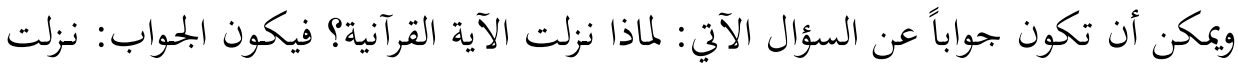
ل التخبر، أو نزلت لتأمر، أو لتنهى.

المستوى الثاني: العلل والحكم والمعاني المستنبطة من الخطاب، ويمكن أن تكون جواباً

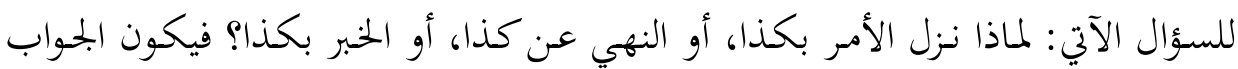
بيبان العلة، أو الحكمة، أو المعنى، أو العبرة. المستوى الثالث: هي المقاصد العليا والعامة والغايات التي يمكن تحصيلها من بجموع

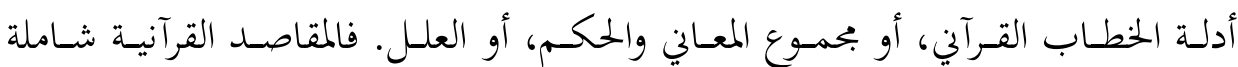

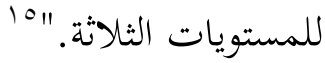

\section{r r تقسيم المقاصد وتصنيفها بين النقد والطموح:}

لا يمكننا إدراك دلالة النص على معناه الكلي إلا بوصفه بنيةً كبرى شاملةً دلالات

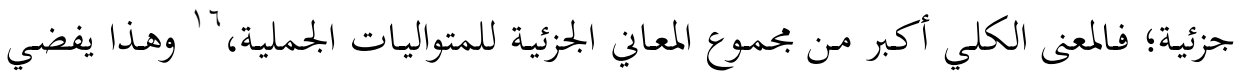

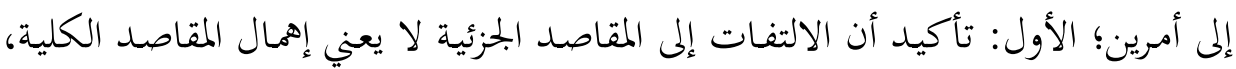

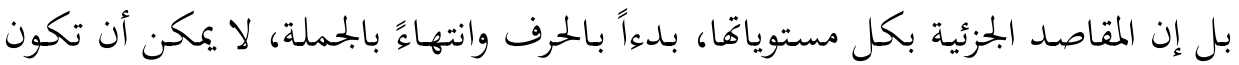
وجهتها في الكلام البليغ إلا من أجل المعنى الكلي.

والأمــر الثـاني: إقـرار أن التصـنيف المقاصـدي قــ يختلـف مـن جهـة الاعتبـار في التصنيف من دون اختلافه في حقيقة ما ينجم عنه في المآل من مقاصد عامة وكلية، وهو

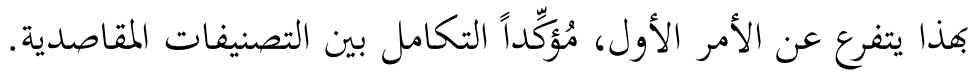

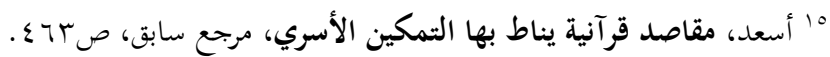

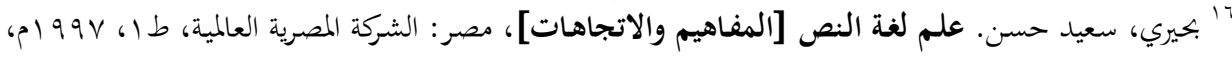




\section{أ. المقاصد القرآنية في الدراسات القرآنية المعاصرة:}

اعتنى المفسرون المعاصرون بتجلية المداية القرآنية، والعلل، والحلكم التشريعية، والعبرة

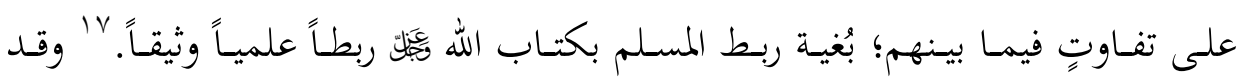
صاحب هذا التفات المصنفين في علوم القرآن إلى الهدف والمقصد القرآين، فصار يُشترَّط

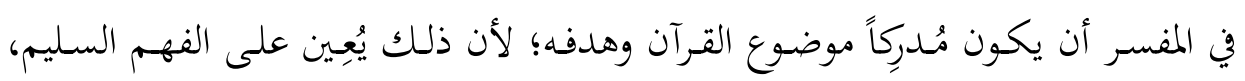

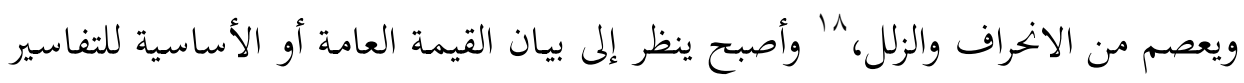

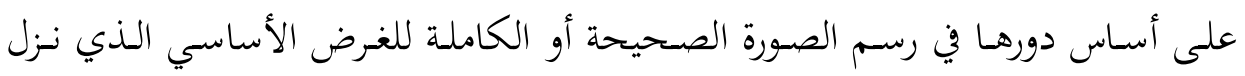

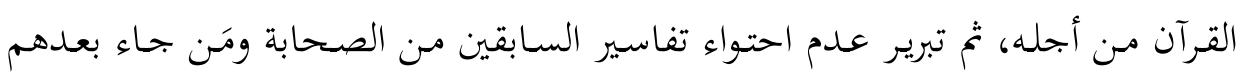

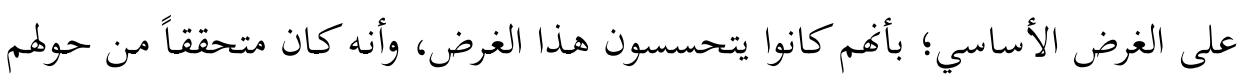
في البحتمع الإسلامي.

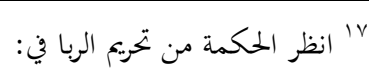

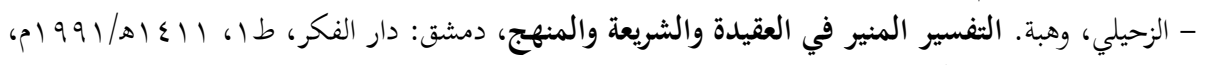

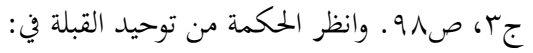

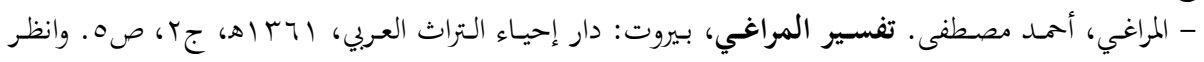

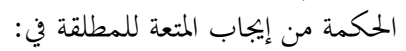

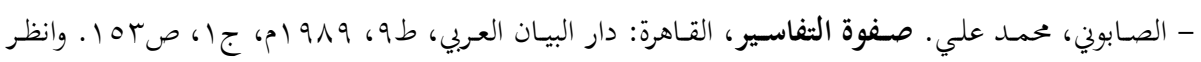
أصول الهداية القرآنية في: الصئ:

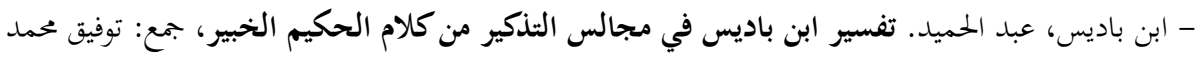

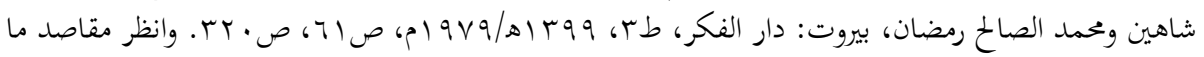

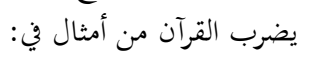

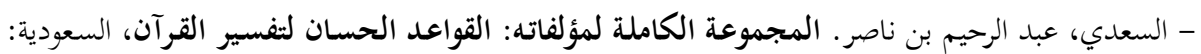

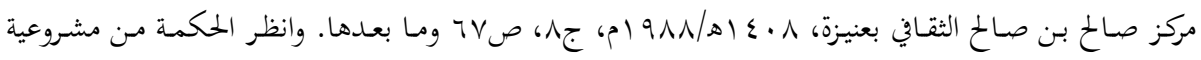
القتال في:

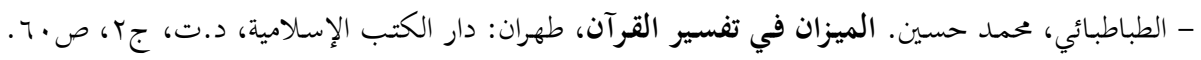

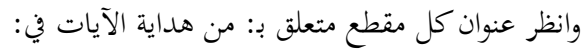

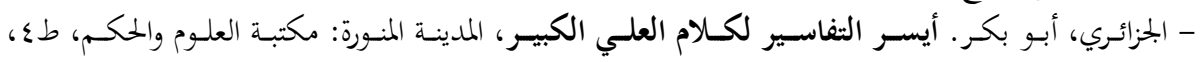

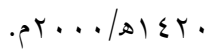

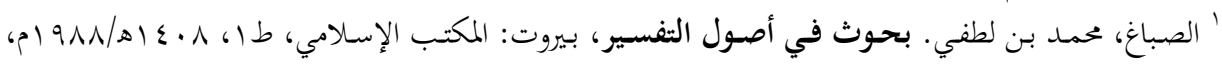

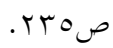

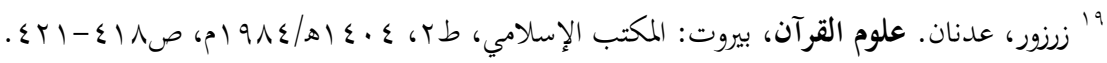


وقد اهتمـت كتب علوم القـرآن ببيـان التعليلات الخارجيـة، مثل الحكمـة مـن نزول

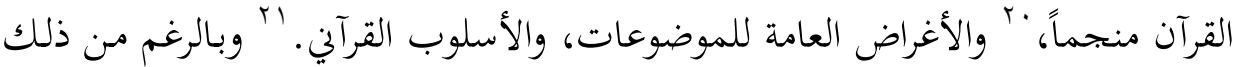

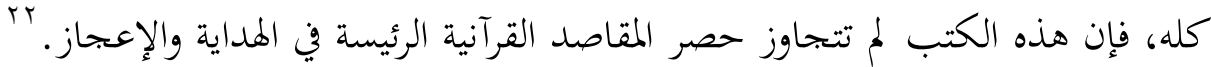
وأمَّا ما يتعلق بالأغراض والأهداف لكل سورة ومقاصدها في القرآن بَ فإن المصنفين

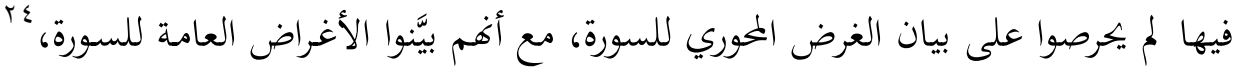

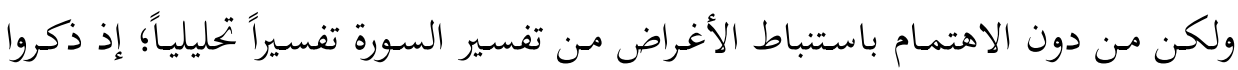

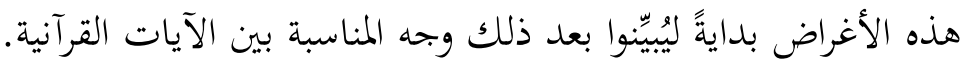

وفي هـذا السـياق، فإِان بعض الدراسـات القرآنيـة المعاصـرة اهتمـت بتجليـة المقاصــ

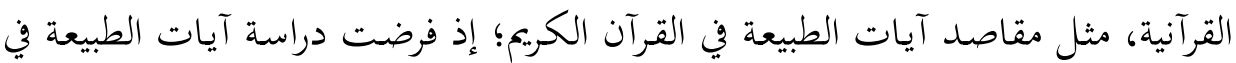

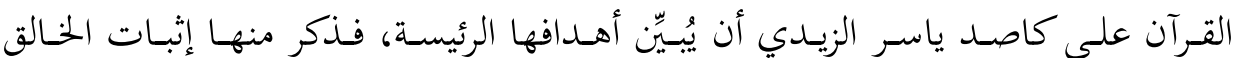

$$
\begin{aligned}
& \text { •r المرجع السابق، ص997 وما بعدها. } \\
& \text { ابr مثل أغراض القصعص والقسم. انظر، }
\end{aligned}
$$

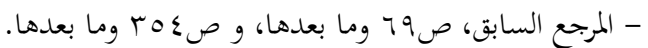

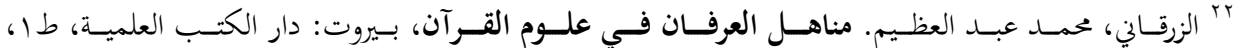

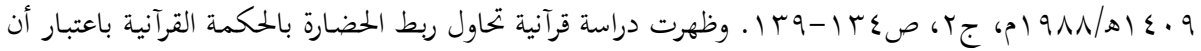

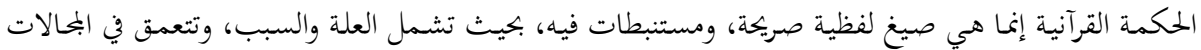

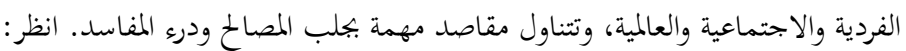

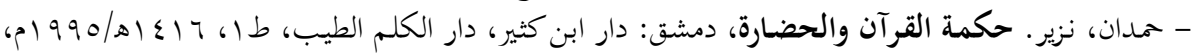
ص ص rar

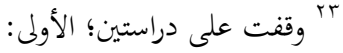

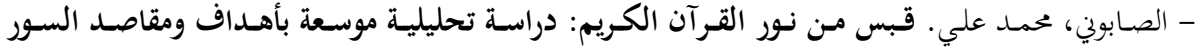

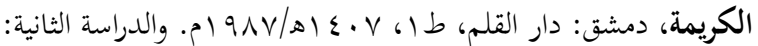

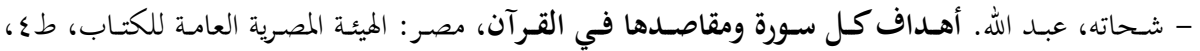
.1991

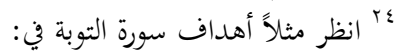
- الصابوني، قبس من نور القرآن آن الكريم: دراسة تحليلية موسعة بأهداف ومقاصد السور الكريمة، مرجع

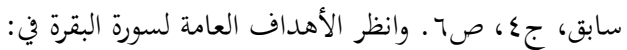

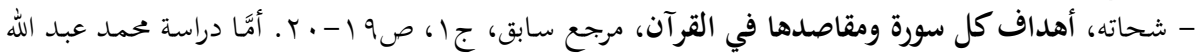

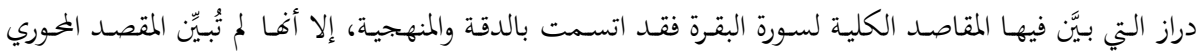

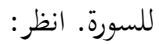




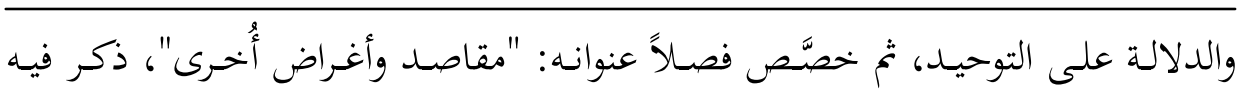

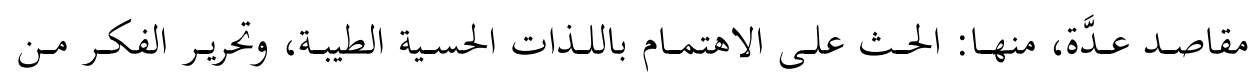
الأوهام.

والـمُالاحَظ على بيـان المقاصـد في هـذا البحـث أهـا لم تتجـاوز كوفها مقاصـد قريبة، لكنها تعد خطوة أساسية لتوليد المقاصد العليا في أيٍٍ من الموضوعات القرآنية. وِمن الباحثين مَن حصر مقاصد القرآن بسبعة مقاصد رأى أنها مَّا أكد القرآن عليه وكرره، وعُني به أشد العناية، وهي: " ا . تصحيح العقائد والتصورات للألوهية والرسالة والجزاء. ب . تقرير كرامة الإنسان ورعاية حقوقه، خصوصاً الضعفاء من الناس. r. توجُّه البشر إلى حسن عبادة الله تعالى وتقواه. ع ـ الدعوة إلى تزكية النفس البشرية. ه . تكوين الأسرة الصالحة وإنصاف المرأة. ج ـ بناء الأُمة الشهيدة على البشرية.

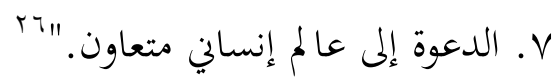
ومسن الجمديـد ذكره أن كل مقصـد مـن هـذه المقاصـد قـد استقرأ مـن مقاصـد أُخرى مستنبطة ومستتقرأة من التقريرات والتأكيدات القرآنية، مثل المقصد السابع الذي يتجلَّى في جملة مبادئ أو قيم عليا دعا إليها الإسلام، وهذه أهمها: ا ـ تحرير الإنسان من العبودية للإنسان. r ـ الأخوة والمساواة الإنسانية.

هب الزيدي، كاصد ياسر. الطبيعة في القرآن الكريم، العراق: دار الرشيد، منشورات وزارة الثقافة والإعلام، ـ19 امب،

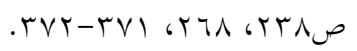

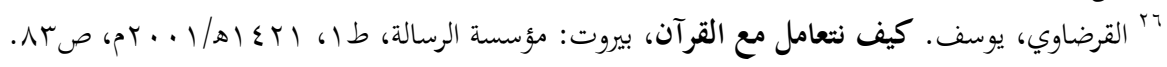


والحقيقة أن هذا البحث لم يكن تفصيلياً كما قرر مؤلّفه في بدايته، ولم يحرص على استقراء جميع الآيات في موضوع واحد، مثل آيات الجهاد، ودراستها لاستنباط المقاصد

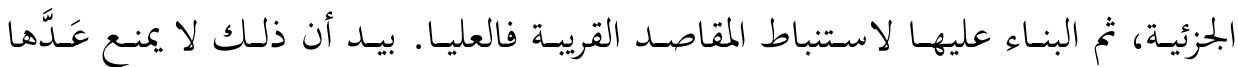
مقاصد مهمة وأساسية، بحيث يمكن أن يكون كلهّ منها موضوع دراسة مستقبلية تُؤِّده أو تنفيه.

وهـذا يعـني أن الدراسـات القرآنيـة التي أريــ فيها (أو مـن بحوثهـا) أن تكشـف عـن المقاصد القرآنية ما تزال محدودة، وأفا تفتقر إلى المنهجية العلمية الموضوعية.

\section{ب. ترتيب المقاصد بين النقد والطموح:}

برزت على السـاحة الفكريـة حسديثاً إشـكالية تصـنيف المقاصـد وترتيبها وحصـرها،

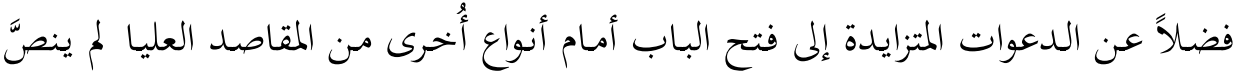

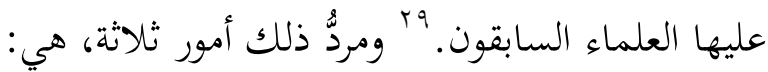

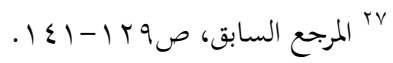

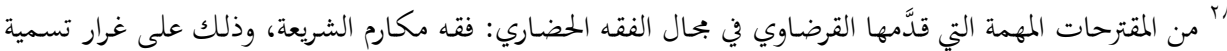

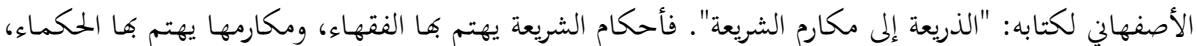

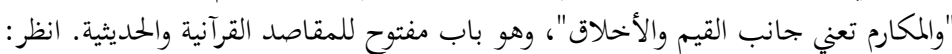

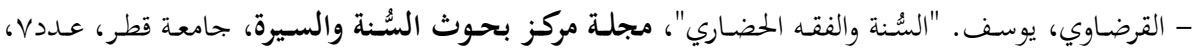

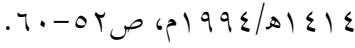

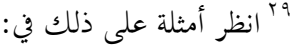

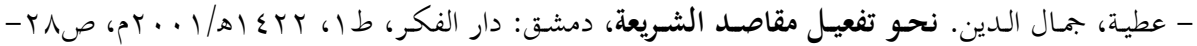
$.1 V Y$

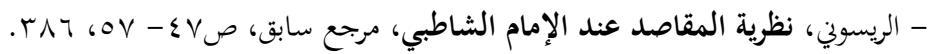

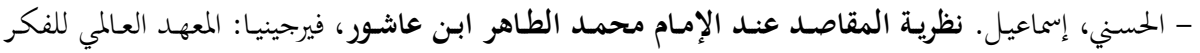

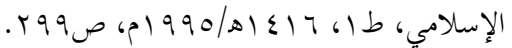

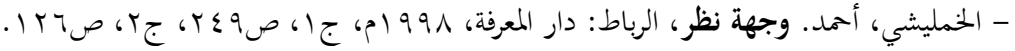


- التغريق بين مقاصد الشريعة ومقاصد القرآن الكريم، وهو مـا ألحت إليه سابقاً، ولم يلتفت إليه معظم الباحثين، ولا سيما أولئك المنادين بإضافة مقاصد أُخرى زيادةً عمَّا ذكره السابقون من الأصوليين، أو بإلغاء هذا التقسيم والإتيان ببديل عنده.

- عـدم اتفـاق البـاحثين على نسـق واحسد في العـودة إلى النصـوص الأولى لاستقراء

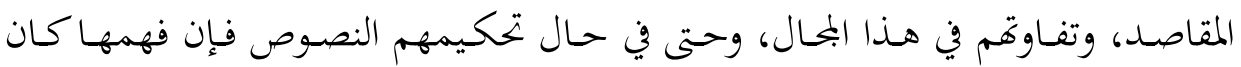

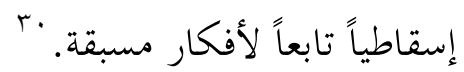

- الإشكالية المتعلقة بقدرة المفسر على استقراء المقاصد القرآنية وترتيبها، ومـا إذا كان النص القرآي يُقدِّم معطيات لترتيب المقاصد. فابن عاشور -مثلاً- لم يذكر تصنيفاً للمقاصد التي عرض لها في تفسيره؛ لأنه كان

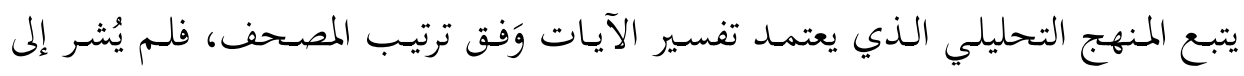

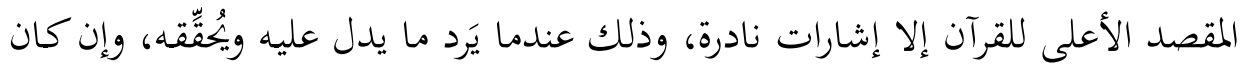

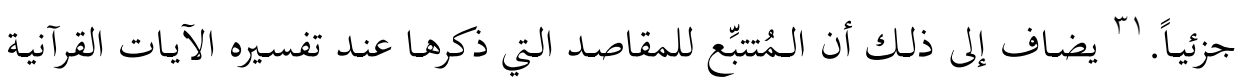
ذات الصلة بالمقاصد الأصلية التي عرض لها في مقدمته؛ يلحظ أهنا مقيدة بما جاء القرآن الكريم لتبيانه في الآيات القرآنية، من دون الالتفات إلى إبراز مقاصد الآيات التي يجمعها

$$
\text { موضوع مشترك. }
$$

- محمد، يجيى. "نظرية المقاصد والواقع"، مجلة قضايا إسلامية معاصرة، إيران، عددم، 999 1م، صلـا I .101

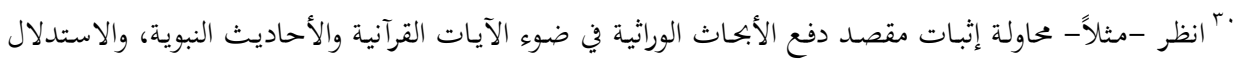

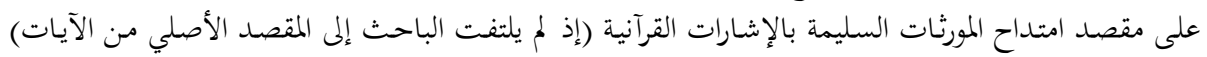

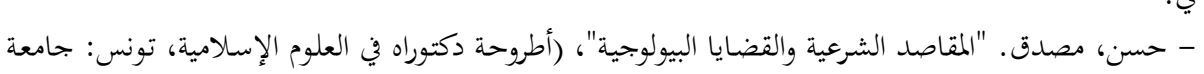

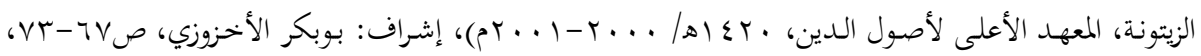
$9 r-11$

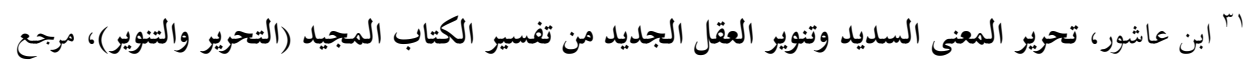

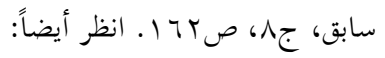

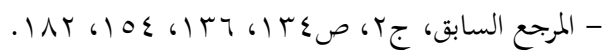
"rr وإن كان في بعض الأحيان يُيِّن المقصد من آيتين أو أو عدَّة آيات متعاقبة. انظر مثلاً: 


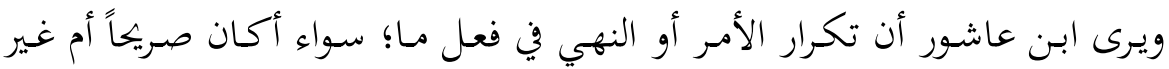

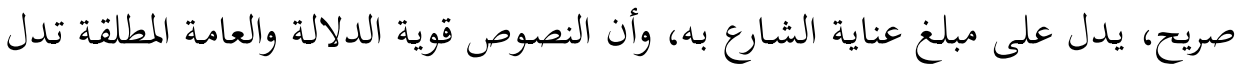

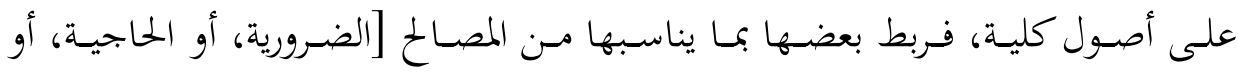

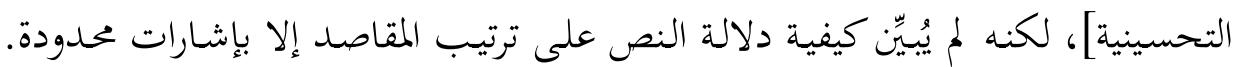

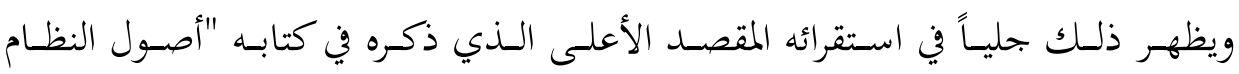

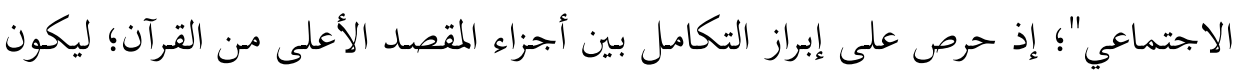

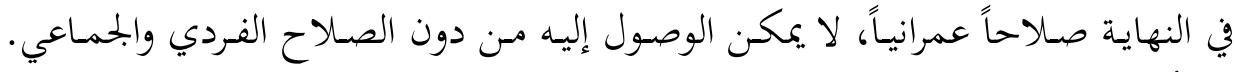

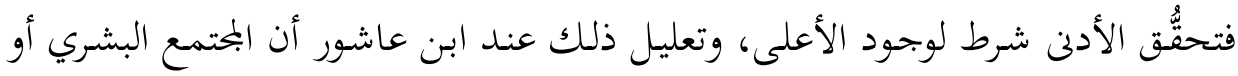

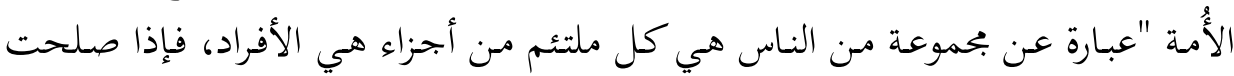

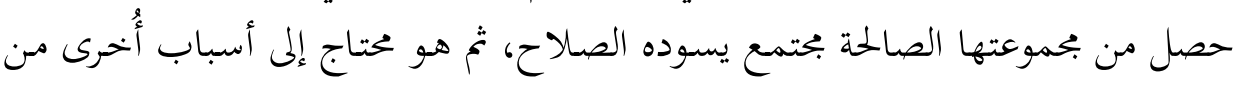

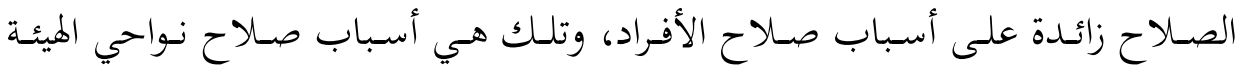

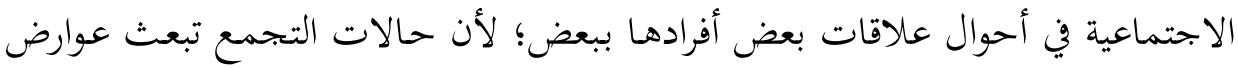

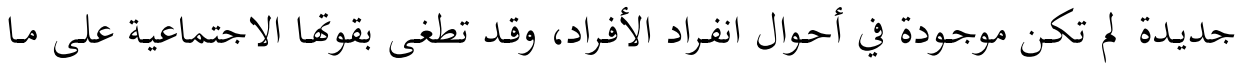

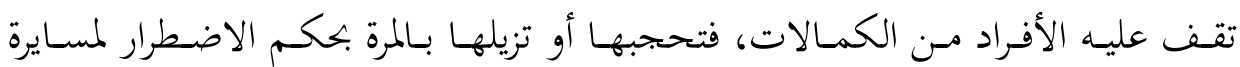

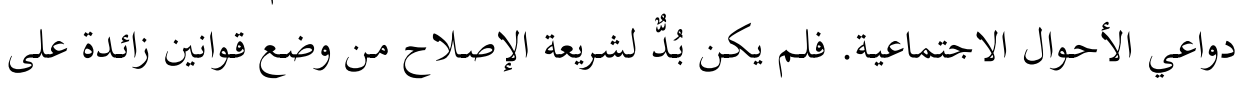

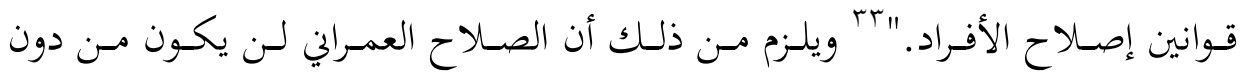

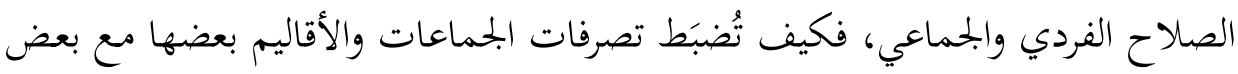

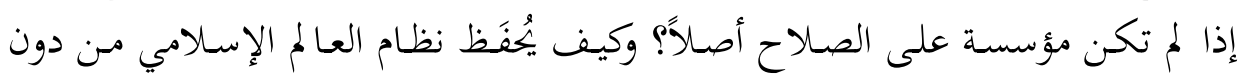

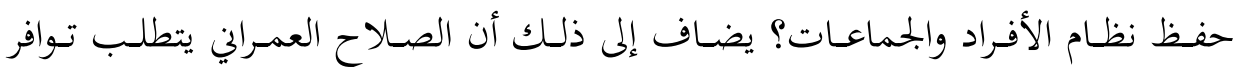

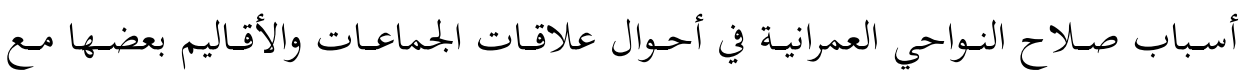

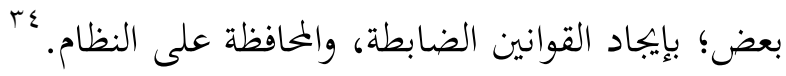

- ابن عاشور، تحرير المعنى السديد وتنوير العقل الجديد من تفسير الكتاب المجيد (التحرير والتنوير)،

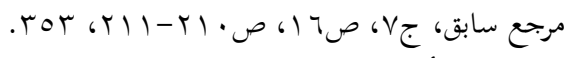

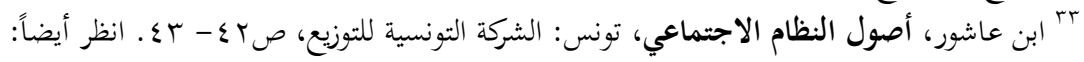

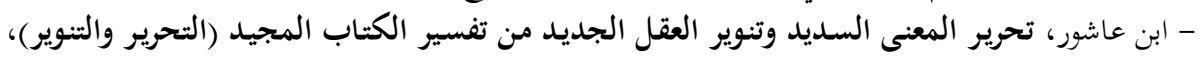

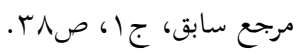
"م"ابن عاشور، تحرير المعنى السديد وتنوير العقل الجديد من تفسير الكتاب المجيد (التحرير والتنوير)، مرجع 
ولكن، إذاكان ابن عاشور يبرهن على ضرورة هذه المراتب عملياً، فما دليله على

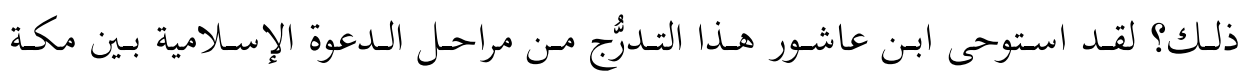
والمدينة، فكانت معظم المرحلة الأولى مُوجَّهة إلى الإصلاح الفردي، والثانية إلى الإصلاح

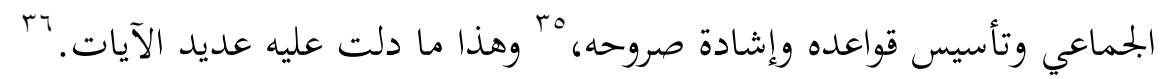

وعدم التفات المفسرين إلى ذلك لا يلغي المعطيات القرآنية بخصوص أهمية المقاصد

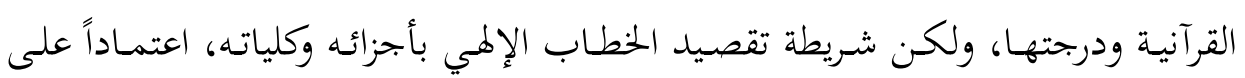
القرائن السياقية والحالية. وقد نبَّه الأصوليون لبعض هذه المعطيات النصية وغير النصية، بسؤاهم مثلاً: هل يمكن تحديد درجة المصالح وَفق الأوامر والنواهي القرآنية؟ وأمَّا علماء

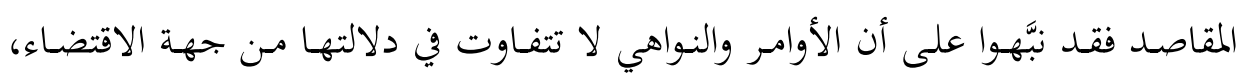
وإنما يكون التفاوت بين المطلوبات من جهة جلب المصالح ودرء المفاسد. "rV ولكن، هل كـان مـن أهـداف القـرآن الكـيم التنبيـه على رتبـة المقاصـد القرآنيـة أو أن ذلك مـتروك

\section{للمصلحة؟}

إن الإجابة عن هـا التساؤل تحتـاج إلى بحـث مستقل، ولكـن يكفي في هـا المقـام

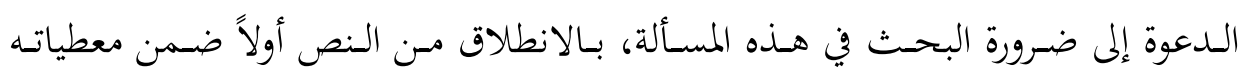

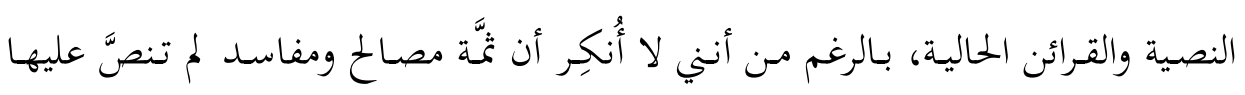

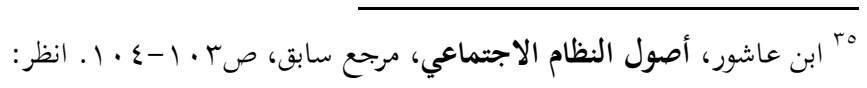

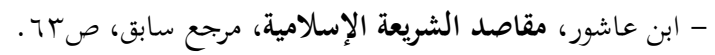

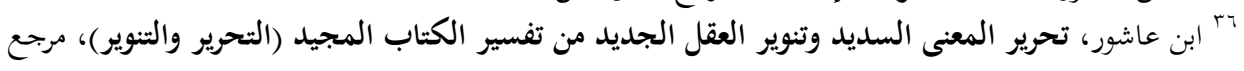

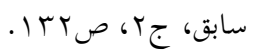

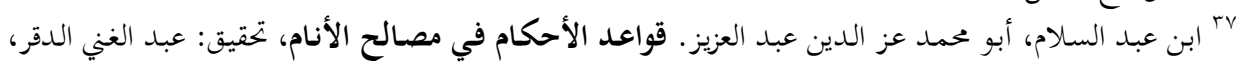

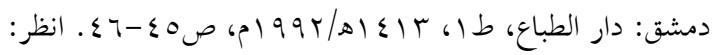

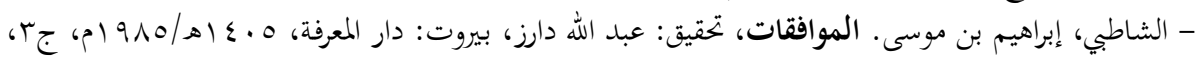

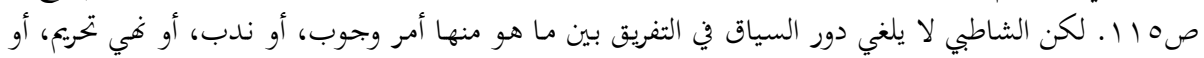

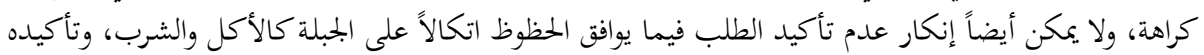

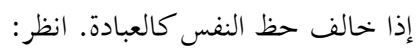

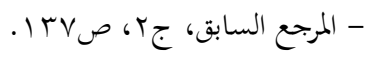


الآيـات القرآنيـة، وإنمـا أدَّعي أن تقصيد الآيـات بأجزائها وكلياتها قد يوصل إلى الإجابة

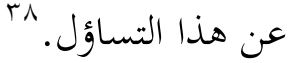

وفي هـا السياق، فقـد اجتهـ الباحث عز الدين بـ سعيد كشـنيط الجزائري في أن يضـع تصـنيفاً لأمهات مقاصـد القرآن، واقترح معايير مختلفـة لترتيبها وتصسنيفها، ولكن

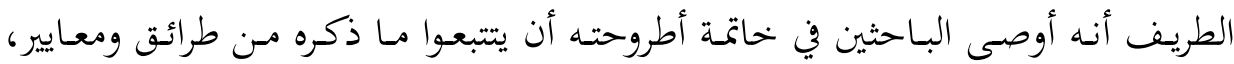

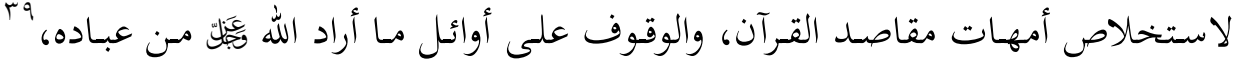

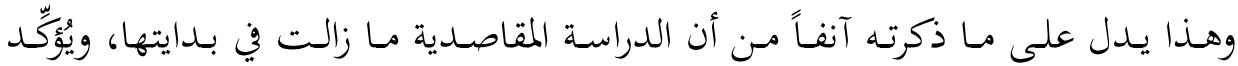
ضرورة تضافر الجهود لبناء المنظومة المقاصدية القرآنية.

\section{ثانياً: تعريف الثفسير المقاصدي للقرآن وإثبات مشروعيته}

التفسير المقاصدي هـ مركَّب وصفي مـن التفسير والمقاصد؛ ومقاصد القرآن سبق

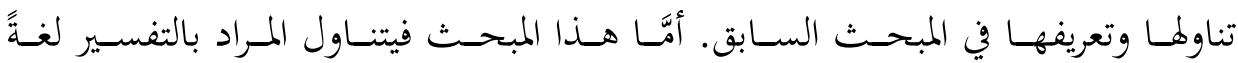
واصطلاحاً، ثم تعريف التفسير المقاصدي.

\section{1 ـ التفسير في اللغة والاصطلاح:}

التفسير لغةً مـن الفسر، والفسر في اللغة أصل يدل على البيان والإيضاح، •؛ ومـن

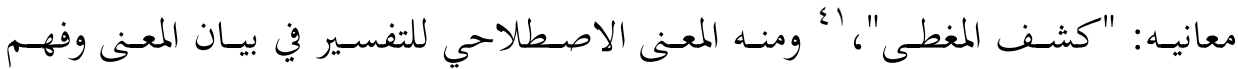

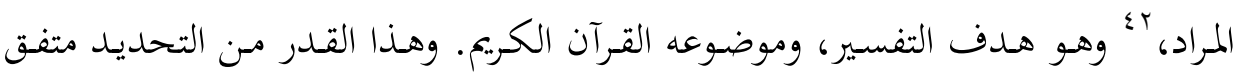
عليه بين العلماء المُعرّفين للتفسير في الاصطلاح.

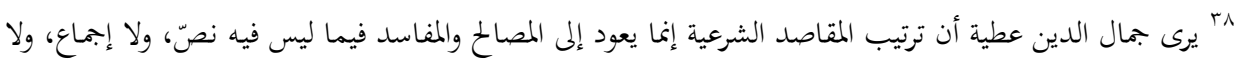

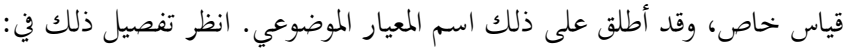

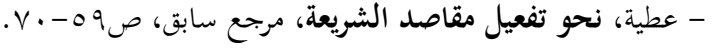

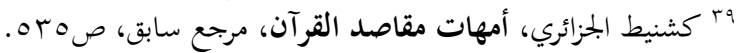

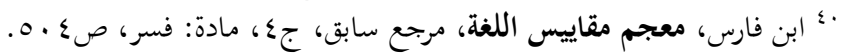

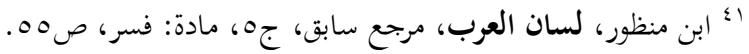

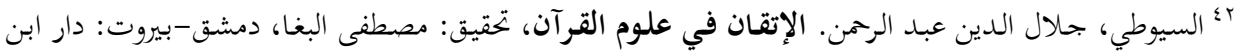

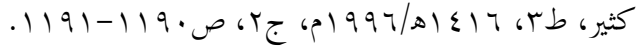




$$
\text { وفيما يأتي بعض تعريفات التفسير في الاصطلاح: }
$$

- "شرح القرآن وبيان معناه، والإفصاح بما يقتضيه بنصه، أو إشارته، أو فحواه." "بع

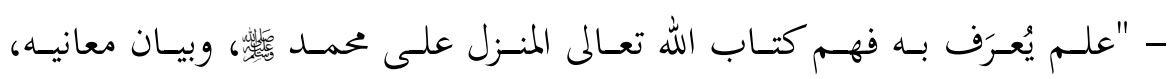

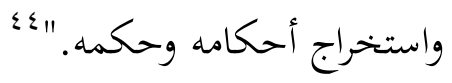

- "اسم للعلم الباحث عن بيان معاني ألفاظ القرآن، وما يستفاد منها باختصار أو توسع." (1) - "علم يُبحَث فيه عن القرآن الكريم من حيث دلالته على مراد الله بقدر الطاقة

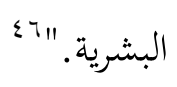

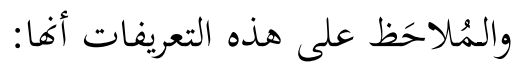
أ. لا بتعل التفسير يقتصر فقط على شرح ألفاظ القرآن الكريم، أو تفسير مشكله، وإنما تتوسع فيه بحيث يشمل بيان الحكم وأحكامه وما يستفاد من معانيه.

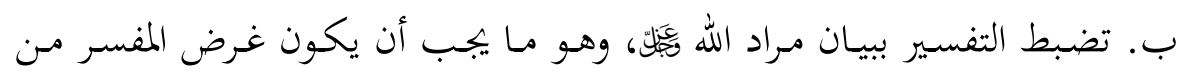

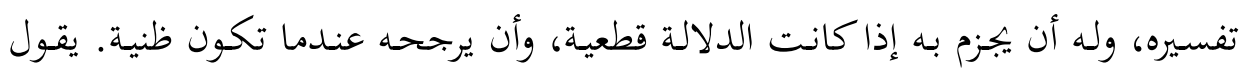

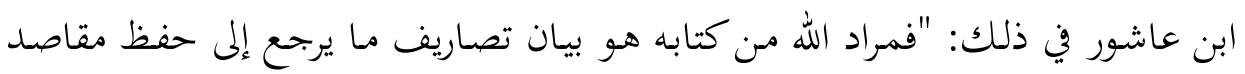

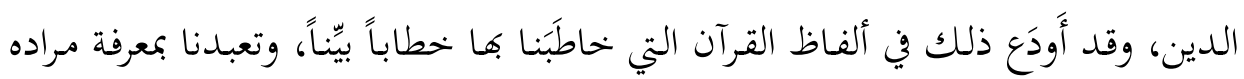

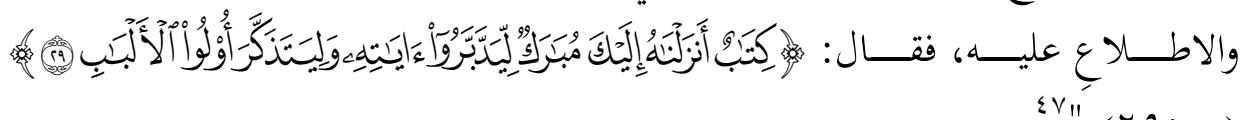
. (ص: ( )

باء ابن جزي الكلبي الغرناطي، محمد بن أحمد. التسهيل لعلوم التنزيل، تحقيق: عبد الله الخالدي، بيروت: دار الأرقم

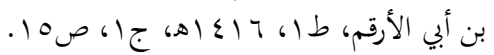

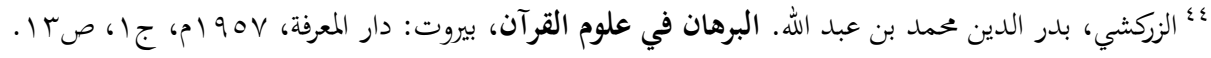

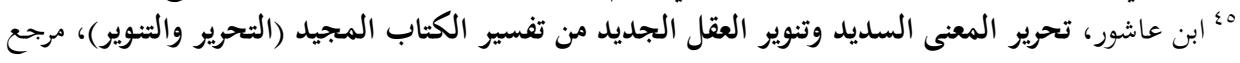

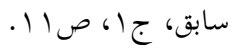

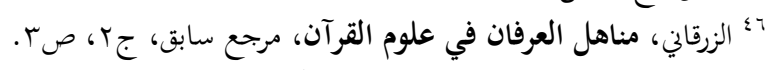

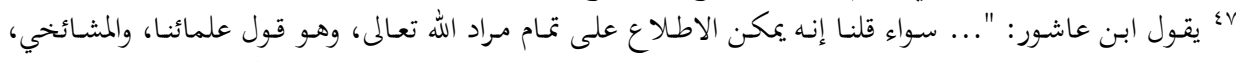

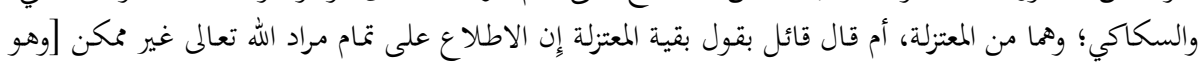

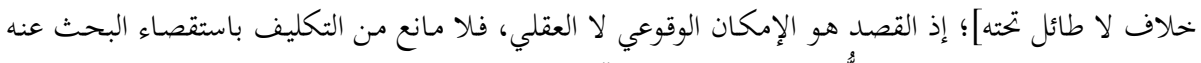

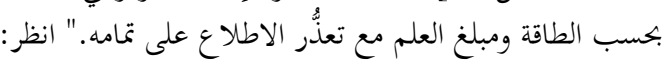


ت. لا تُقيِّد التفسير بمنهج أو ابتحاه تُحََّّد.

\section{Y. تعريف التفسير المقاصدي في الاصطلاح:}

بالرغم من جدة الدعوة إلى هذا النوع من التفسير، فإن ثمَّة تعريفات عدَّة متباينة له؛ إذ تفاوتت جهود الباحثين في التعبير عنه، فقد عُرِّف بأنه: "ذلك النوع من التفسير الذي مني

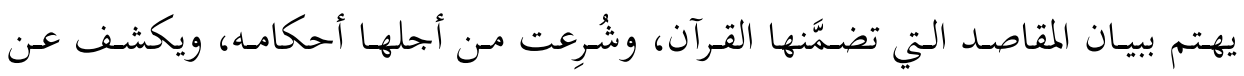

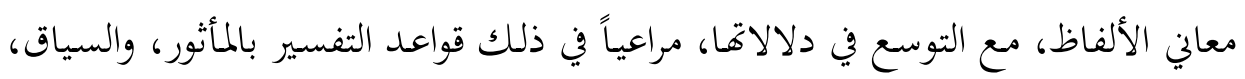
والمناسبات.

ويُلاحَظظ على هـذا التعريـف حصـره التفسـير المقاصـدي في الكشـف عـن مقاصــ الأحكام، فضلاً عن لزوم الدور في تعريفه التفسير المقاصدي ببيان المقاصد.

وأمَّا وصفي عاشور أبو زيد فعرَّفه بأنه: "لون من ألوان التفسير يبحث في الكشف عن المعاني والغايات التي يدور حولها القرآن الكريم كلياً أو جزئياً، مع بيان كيفية الإفادة منها في تحقيق مصلحة العباد." "و؛ ثم يقول بعد ذلك: "والنص على [بيان كيفية الإفادة منها] ]جاء للتأكيد على أن التفسير ليس للتفسير وحسب، وإنما لبيـان كيفيـة استنزال هدايات القرآن للواقع المعاصر، وكيف تفيد منها الدوائر الاجتماعية المختلفة."•

ونحسب أن تنزيل المقاصد على الواقع يعد خطوة لاحقـة للتفسير المقاصدي؛ فلو

أردنا منه أن يكون نوعاً من أنواع التفسير لوجب أن يتقيد بقيده بالاقتصار على التفسير، ولا سيما أن استقراء المقاصد لا بُبَّ فيه من جهد كبير يحتاج فيه الباحث إلى التركيز عليه

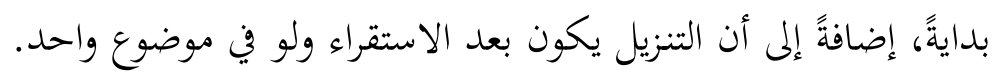

- ابن عاشور، تحرير المعنى السديد وتنوير العقل الجديد من تفسير الكتاب المجيد (التحرير والتنوير)،

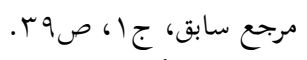

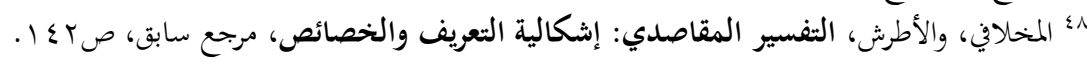

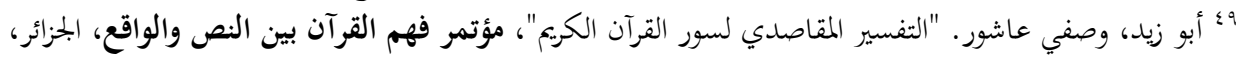

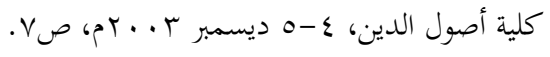
• المرجع السابق، صلصن. 
ولذلك نُعرِف التفسير المقاصدي للقرآن بأنه الكشف عن مراد الله هيَّلن فيما أنزله في

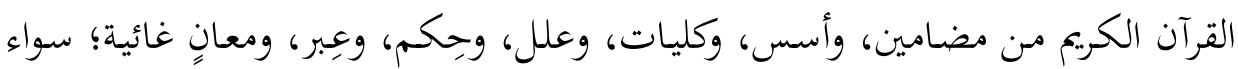

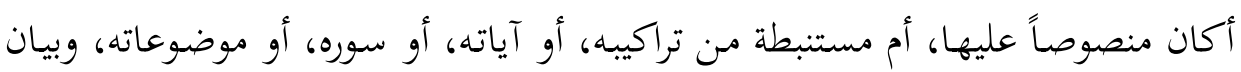
بنائها التكاملي.

ولا نرى أن تعريف الزرقاني للتفسير 'ْيختلف عن تعريف التفسير المقاصدي؛ لأن

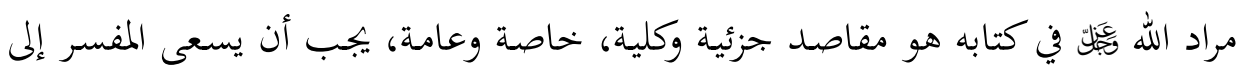
تحصيلها؛ فلو اقتصر في التعريف على الكشف عن مراد الله في القرآن الكريم لكان مُعبِّرً عن ماهية التفسير المقاصدي، لكننا نريد الضبط والتفصيل؛ إذ لا فرق بين غرض التفسير عامة والتفسير المقاصدي؛ فغرض المفسر هو "بيان ما يصل إليه، أو ما يقصده من مراد

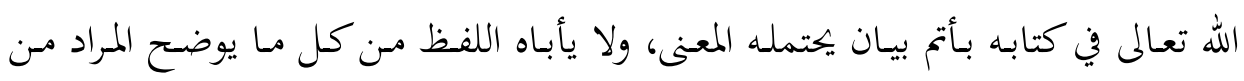

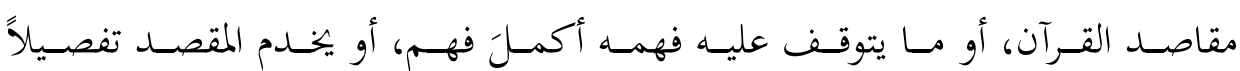
وتفريعاً.

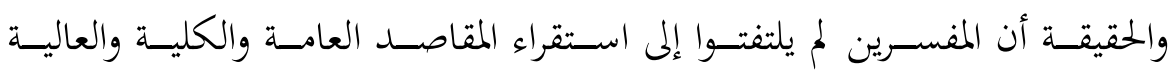

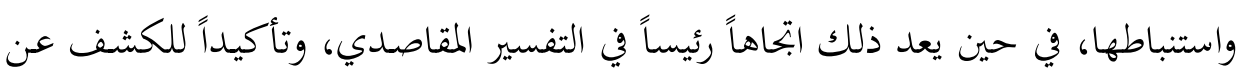

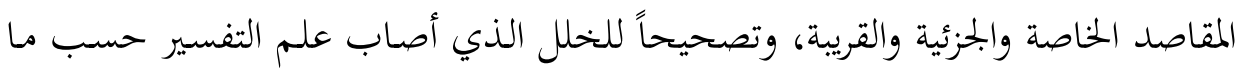
سنذكره لاحقاً.

وقد استعمل معظم الأصوليين مصطلح "المعنى" للدلالة على الحكمة والعلة، وهذا

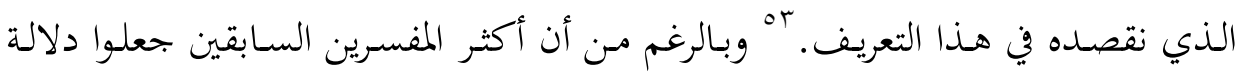

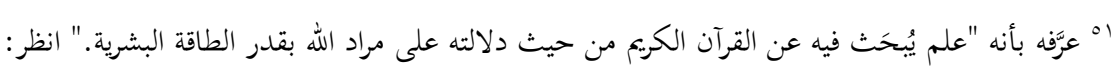

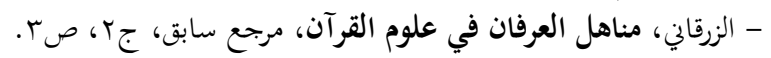

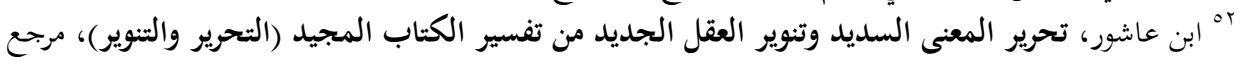

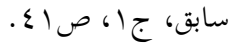

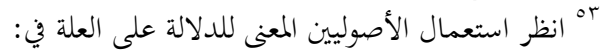

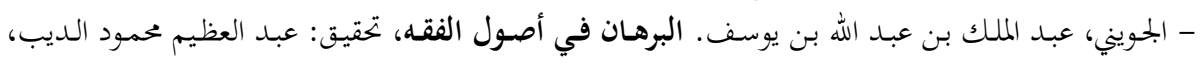

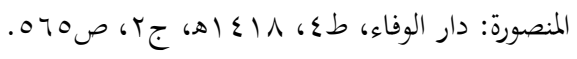




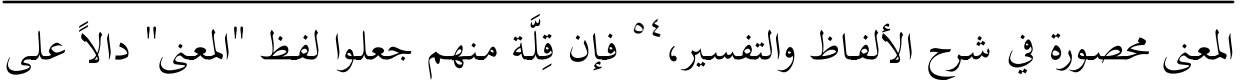

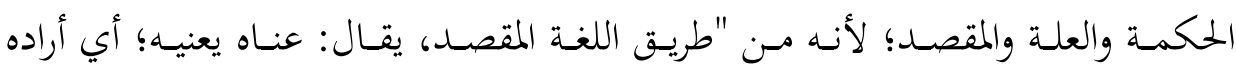

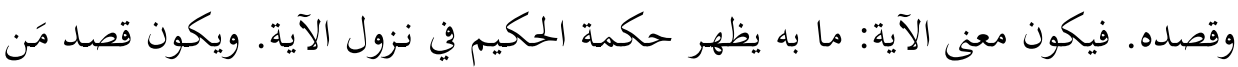

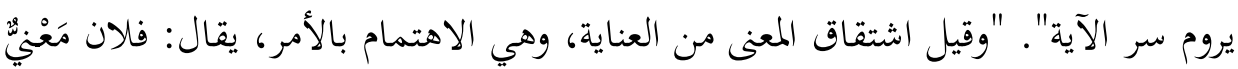

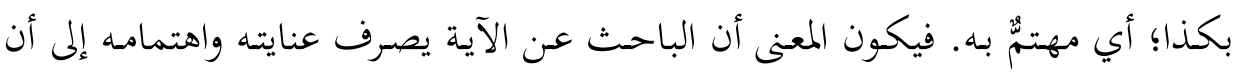

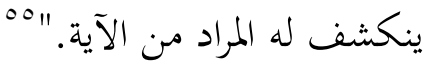

ويفيد لفظ "المعاني" في التعريف جميع المعاني الجزئية والكلية الخاصة والعامـة؛ سواء

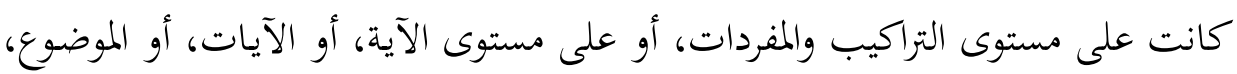

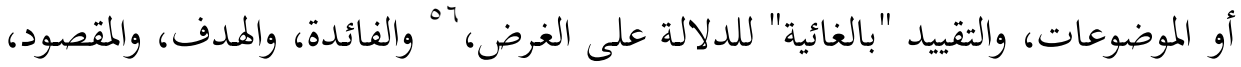

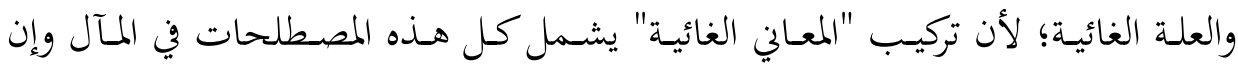
اختلفت من حيث الاعتبار.

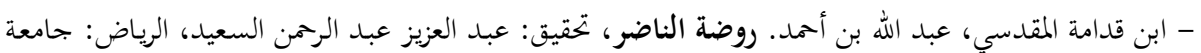

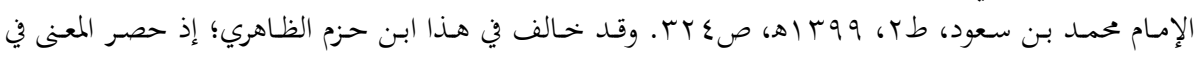

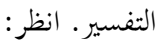

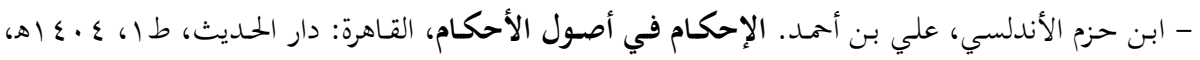

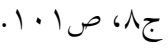
؛

- الطبري، جعفر محمد بن جرير . جـامع البيان في تأويل القرآن، بيروت: دار الفكر، طا، ه ــ اهـ، جا، ص $197-190$ - ابن عطية الأندلسي، عبد الحق. المحرر الوجيز تفسير الكتاب العزيز (تفسير ابن عطية)، تحقيق وتعليق:

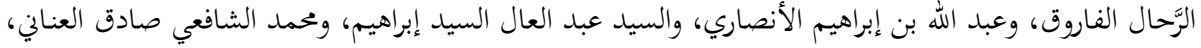

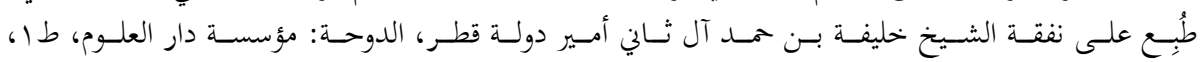
1

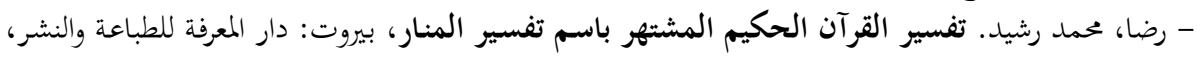

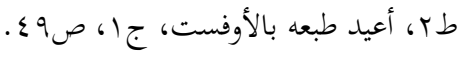
- الألوسي، محمد. روح المعاني في تفسير القرآن العظيم والسبع المثاني، تحقيق: محمد السيد الجلنيد، بيروت:

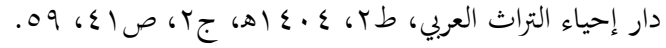

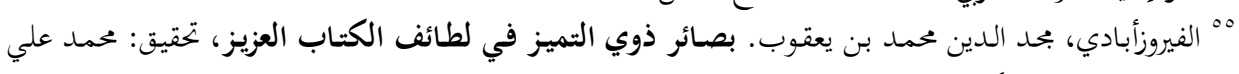

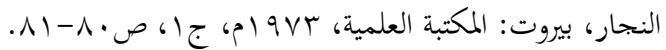

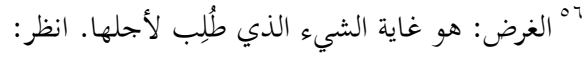

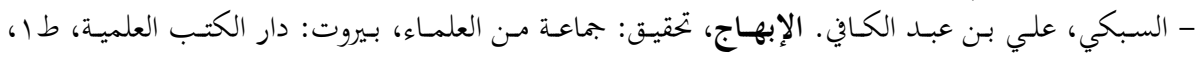

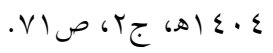




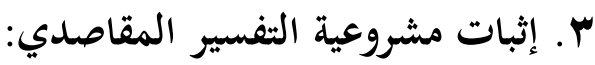

يستمد التفسير المقاصدي مشروعيته من مشروعية التفسير في الوقوف على مراد الله

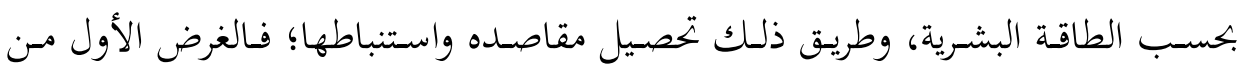

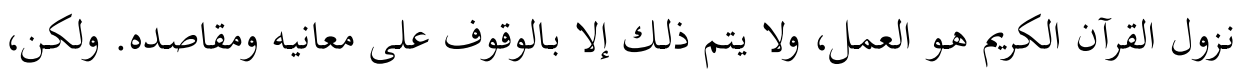

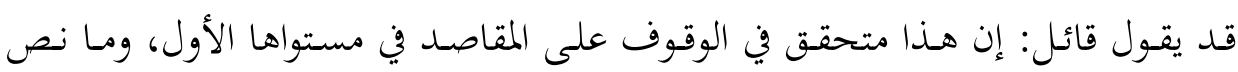

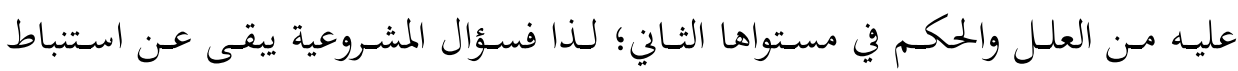
المقاصد في مستواها الثالث ومحاولة ترتيبها.

ومنطلق الإجابة عن ذلك هو القرآن نفسه فيما يحيلنا إليه من التدبر في آياته، قال

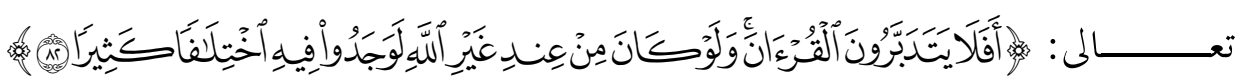

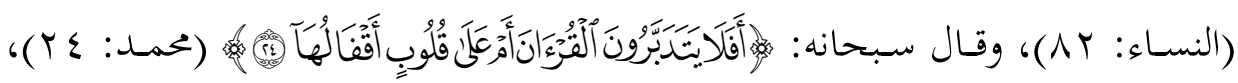
وقال

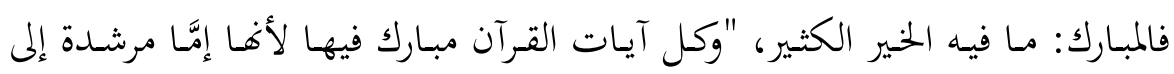

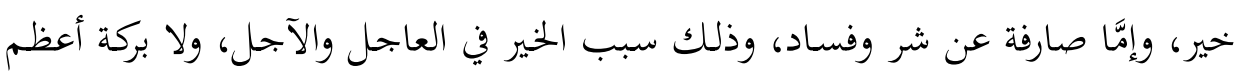

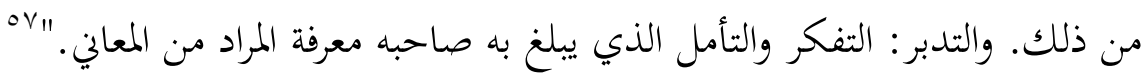
فالآيات تأمر بالثفكر فيها ومعرفة غاياتا، ولو كان ذلك من كلام البشر لوجدوا فيه

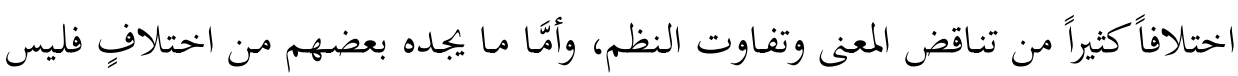

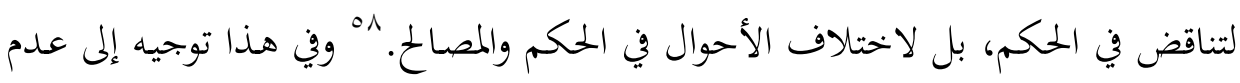

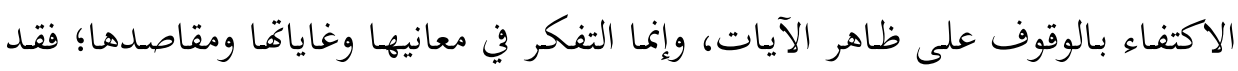

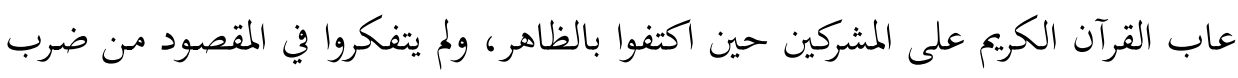
لاه ابن عاشور، تحرير المعنى السديد وتنوير العقل الجديد من تفسير الكتاب المجيد (التحرير والتنوير)، مرجع

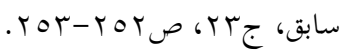

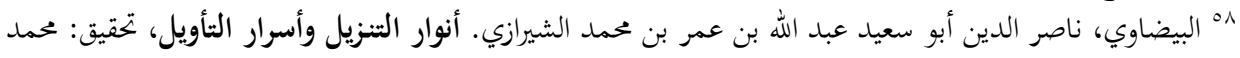

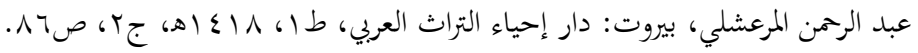




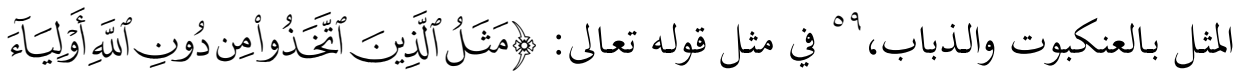

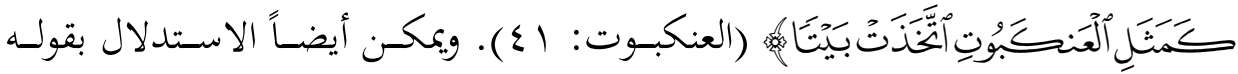

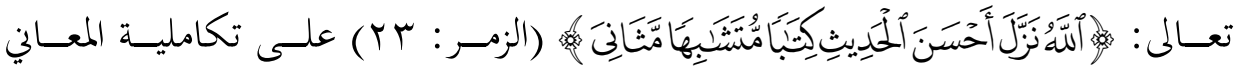

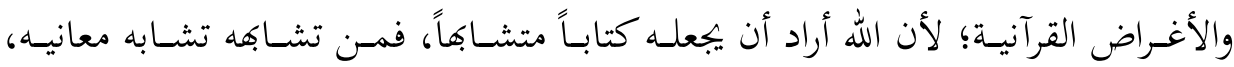

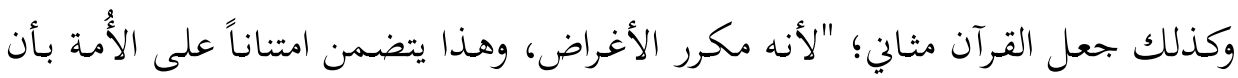

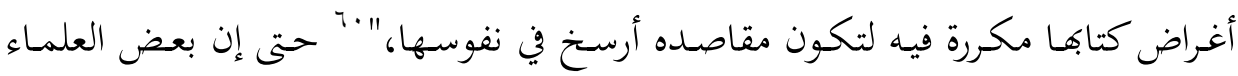

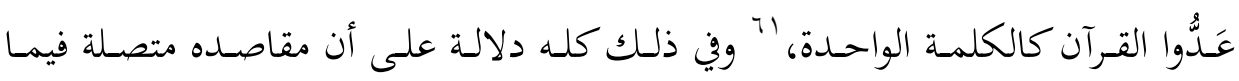

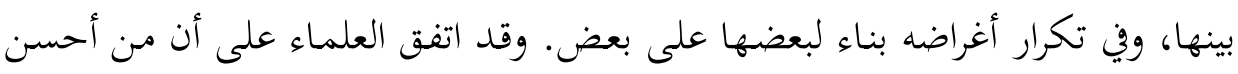

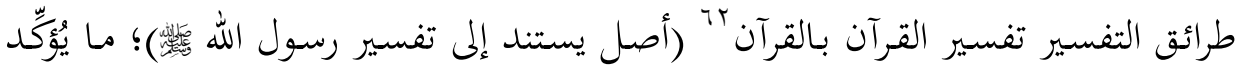
التكامل بين معاني آياته وموضوعاته، ثم وحدة مقاصده.

ولا شكك في أن طبيعة الأفكار والموضوعات الجزئية ذات الصلة بموضوعات أكبر،

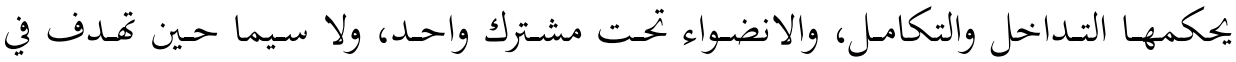

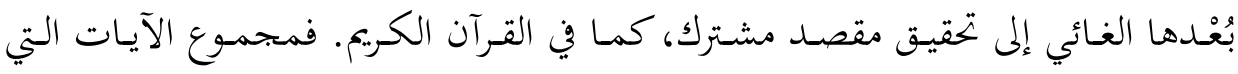

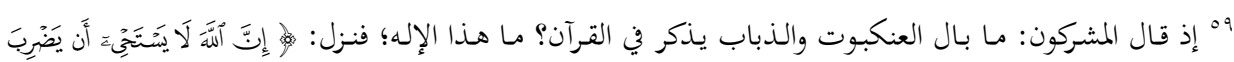

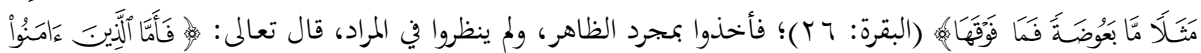

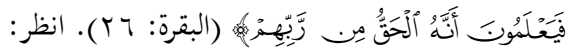

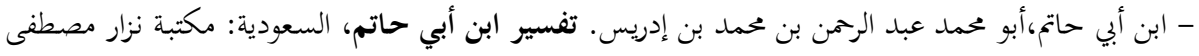

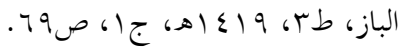

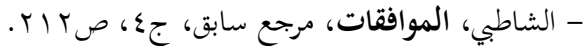
" ابن عاشور، تحرير المعنى السديد وتنوير العقل الجديد من تفسير الكتاب المجيد (التحرير والنتوير)، مرجع

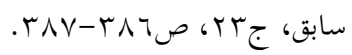

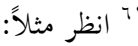

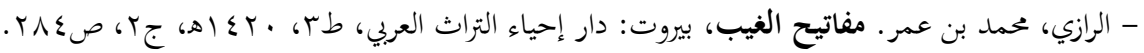

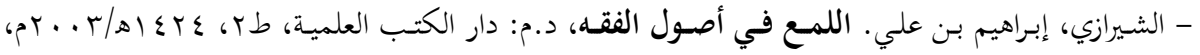

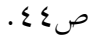

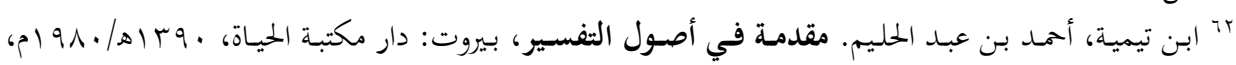

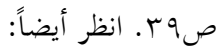
- الدهلوي، أممد بن عبد الرحيم. الفوز الكبير في أصول التفسير، ترجمة: سلمان الندوي، القاهرة: دار

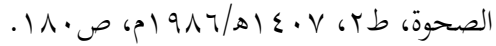


تخاطب الإنسـان، والتي تعرض لكل مـا يصلحه مـن جوانـب مختلفـة، ضـمن مستويات متعددة، يمثل مقاصد خاصة في كل جانب ومستوى، ومقاصد عامة في بحموعها، تدفع إلى البحث في علاقة بعضها ببعض، وترتيبها، وبنائها؛ مـا قد يؤسس لتفسير مقاصدي هدفه الكشف عن هذه المقاصد في مستوياها المختلفة، ودرجاها، ومنظومتها البنائية في القرآن الكريم. ولعل التطبيق هو الذي يُؤِّد هذا أو ينفيه؛ لذا نعرض هاهـ المثال الآتي: المقصد العام الأعلى للقرآن الكريم (إصلاح العالم) يمكن استنباطه من آيات كثيرة

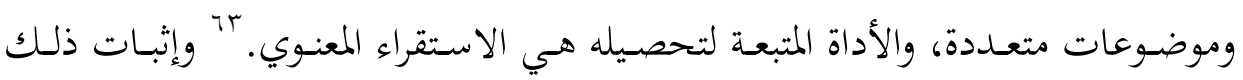
يكون باستقراء: أ. أدلة صريحة كلية تدل على أن مقصد الشريعة هو إصلاح هذا العالم، وإزالة

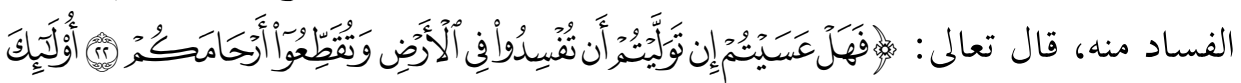

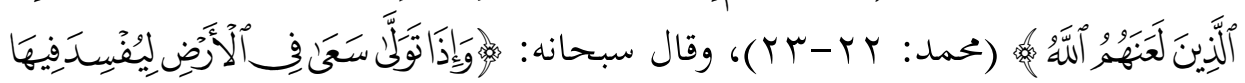

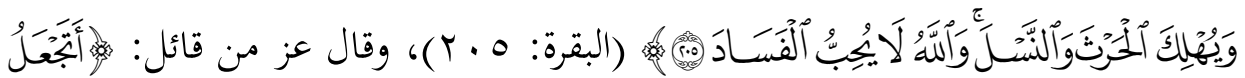

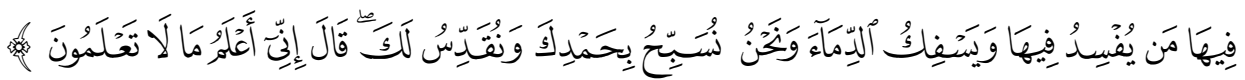
(البقرة: • ب)؛ إذ دل الاستفهام المشوب بالتعجب ونس على أن الملائكة علموا أن مراد الله

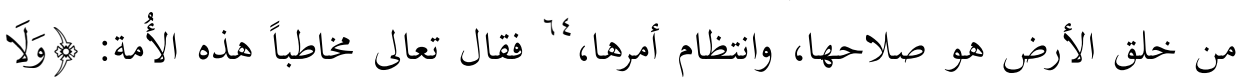

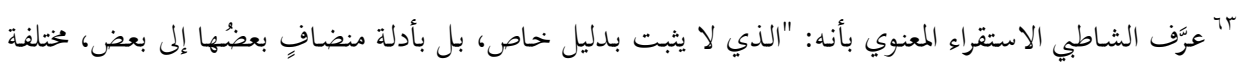

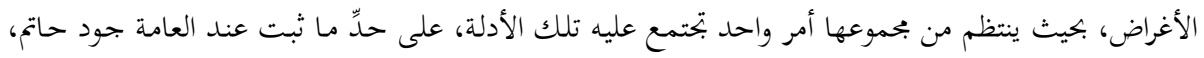

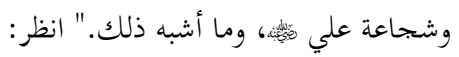

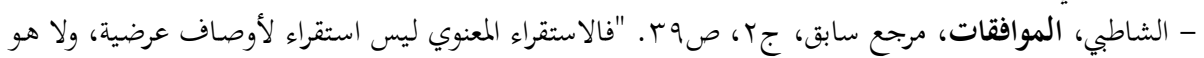

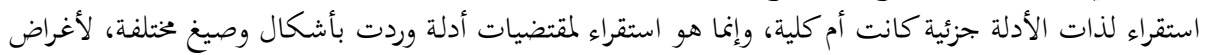

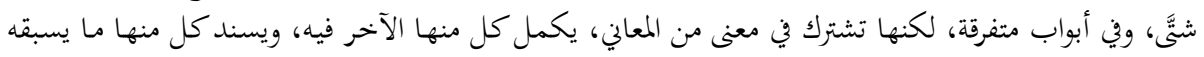

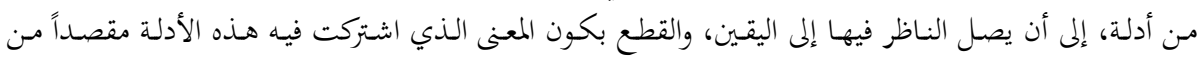

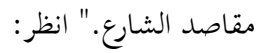

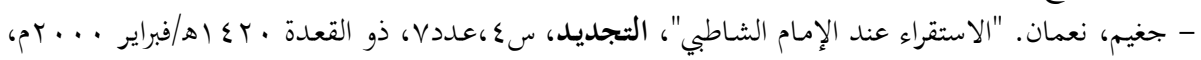

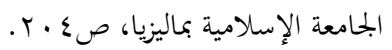

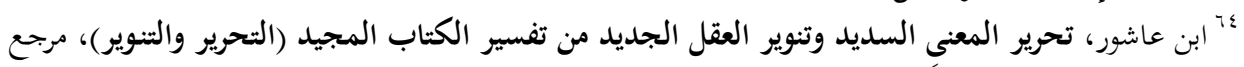

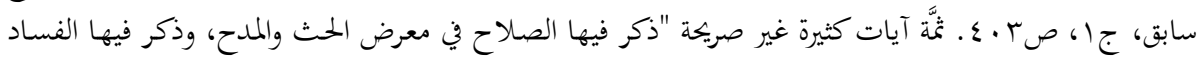

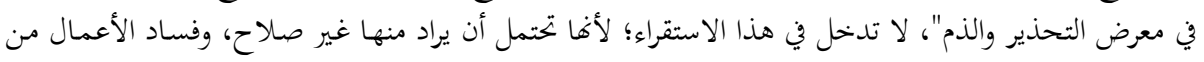
الإيمان والكفر. 


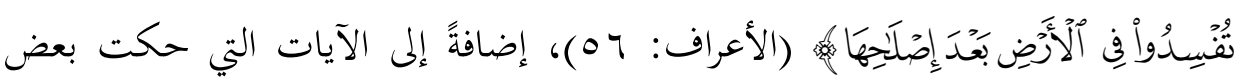
أهداف شريعة الأنبياء السابقين، مثل الإصلاح وعدم الفساد، ومن ذلك ما جاء حكايةً

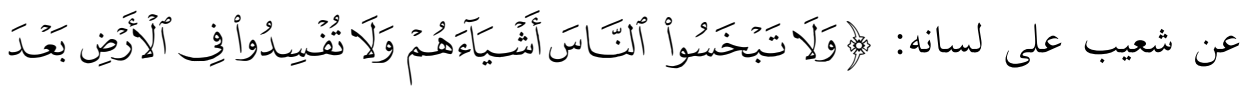

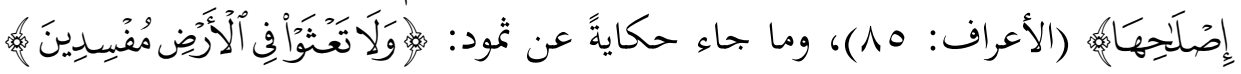

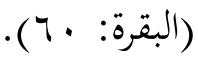

ب. أدلة من قبيل الإيماء جاءت دالة على أن الصلاح في هذا العالمِ مِنَّة كبرى يمَنُّ

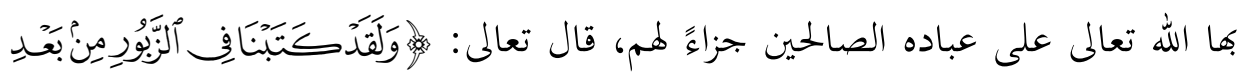

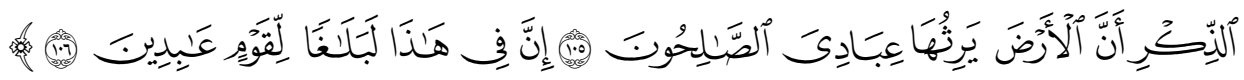

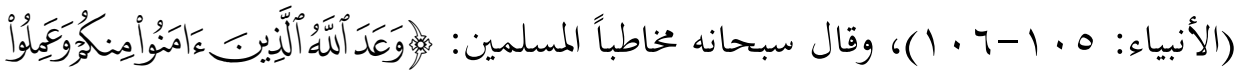

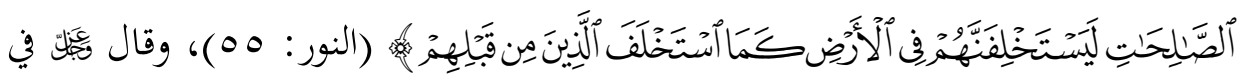

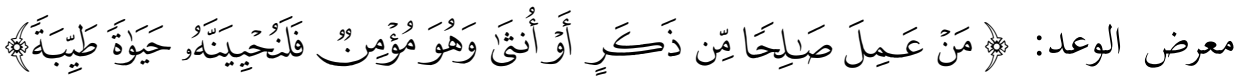

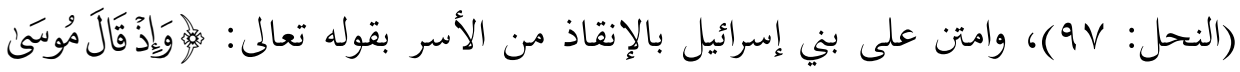

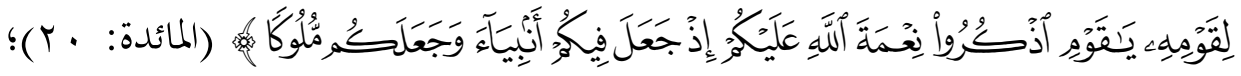
فلولا أن صلاح هذا العالم مقصود للشارع ما امتن الله به على عباده.

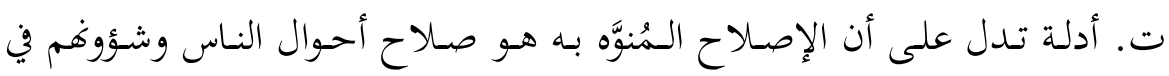

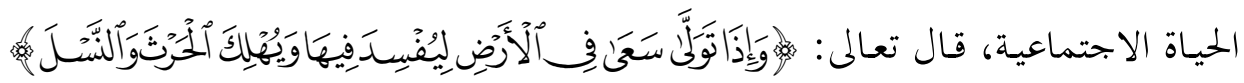

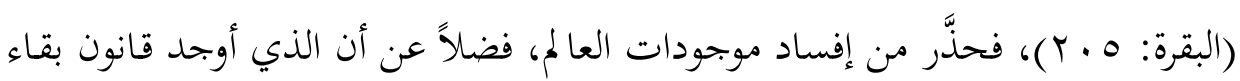

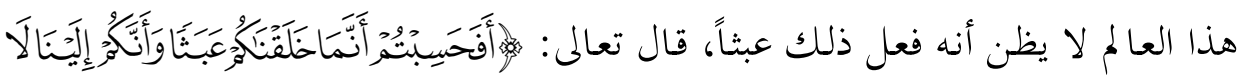

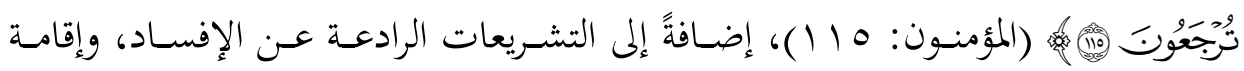

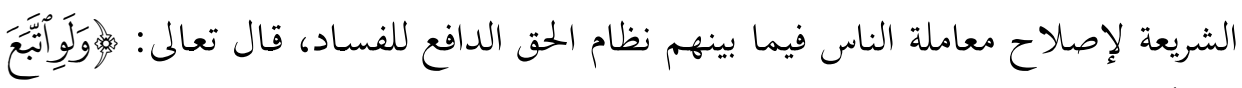

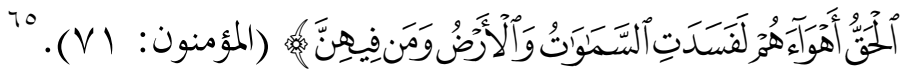

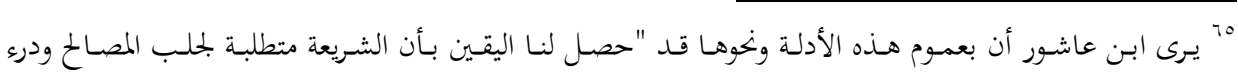

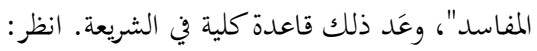

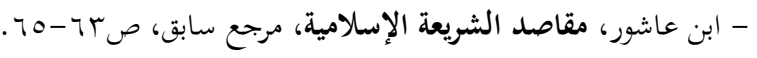




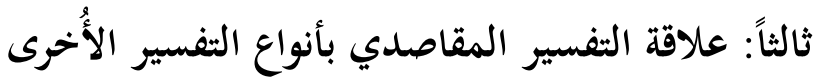

لا شك في أن غاية علم التفسير التي يتعيَّن على المفسر أن يسعى إلى تحقيقها، هي

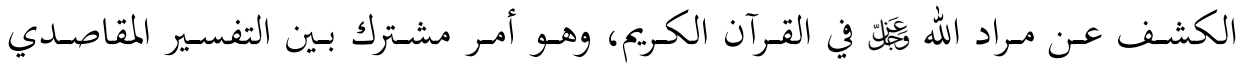

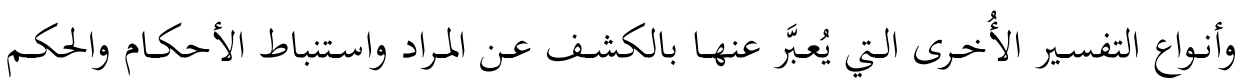

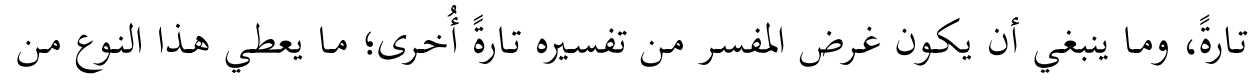

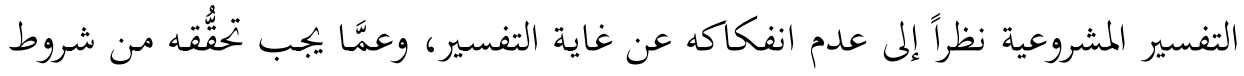

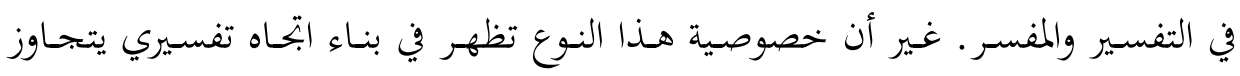

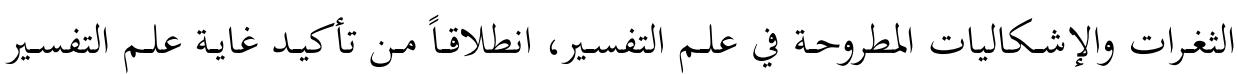

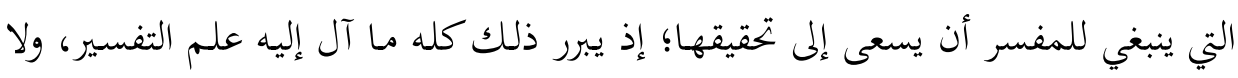

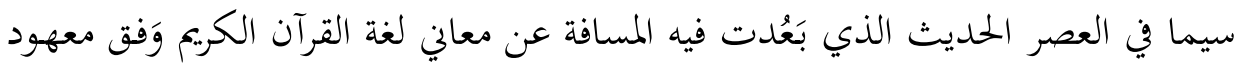

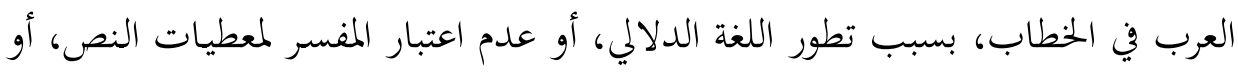

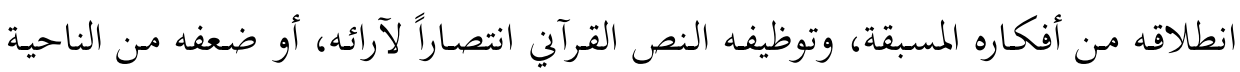

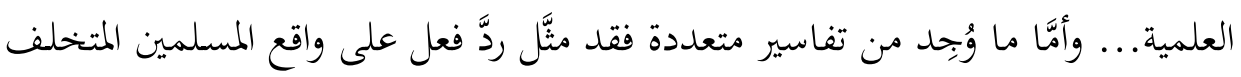

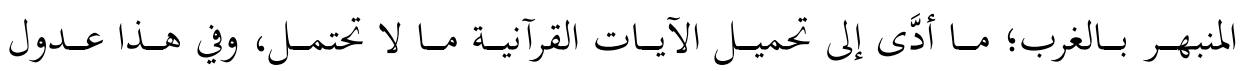

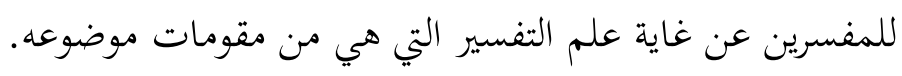

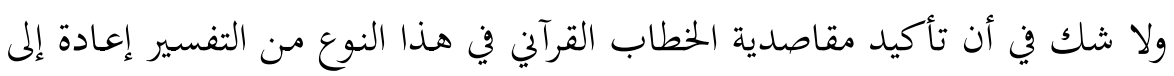

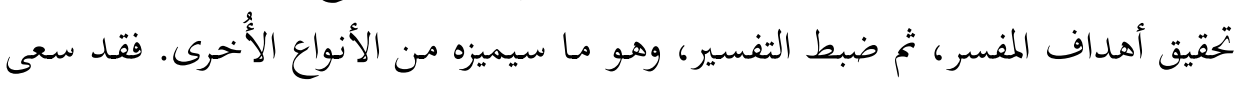

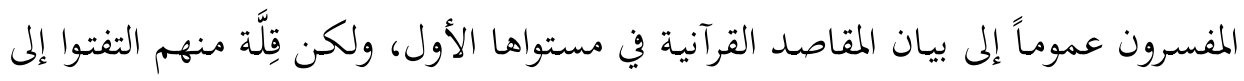

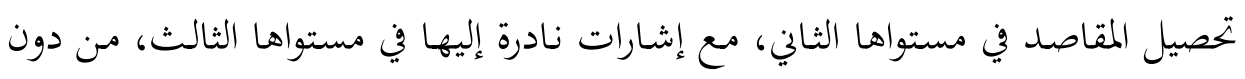

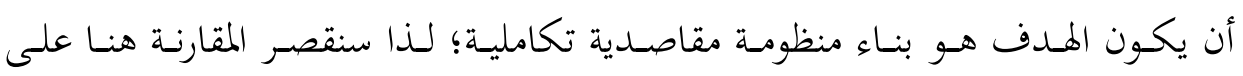
التفسير الموضوعي من باب التمثيل، ولا سيما أنه وثيق الصلة والشبه به، أو تُعَّقاً له.

\section{1 ـ علاقة التفسير المقاصدي بالتفسير الموضوعي:}

إن منهجية البحث في وحدة القرآن الموضوعية تختلف عن الاتجاه المقاصدي فيما 
أ. هدف التفسير الموضوعي للقرآن الكريم هو تمثيل "مقاصد القرآن من خلال إبراز

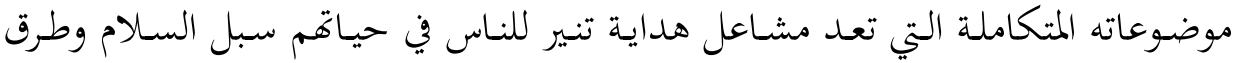

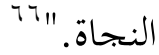

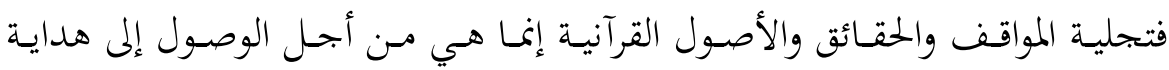

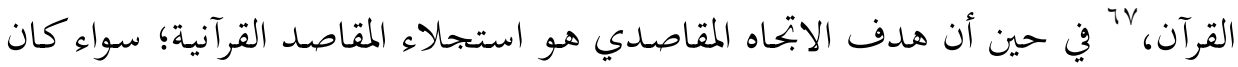

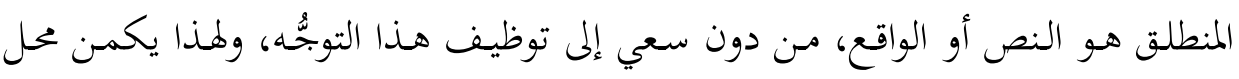

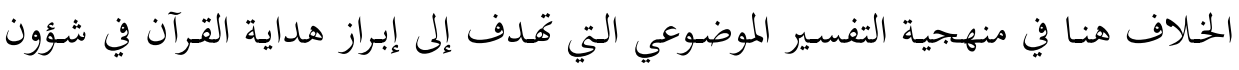

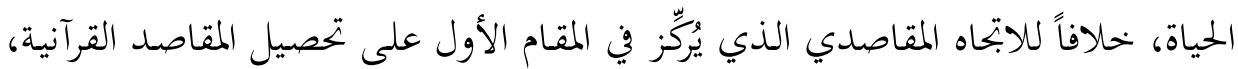
ولا يخفى على أحد أهمية استناد الأول على الثاني، وقد أشرنا إلى ذلك آلى آنفاً.

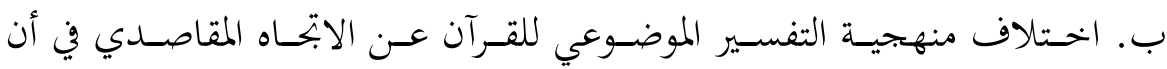

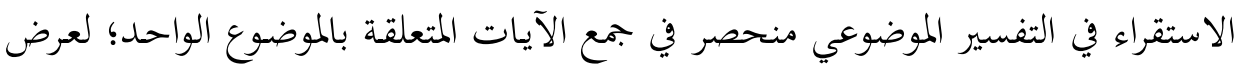

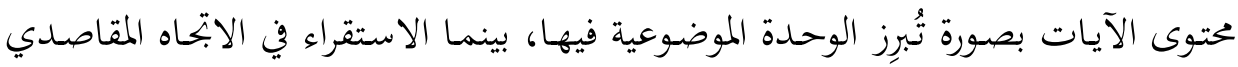

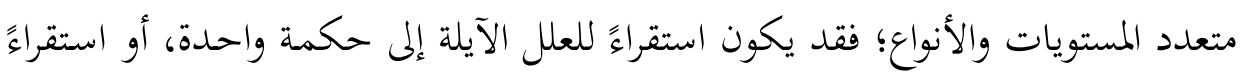

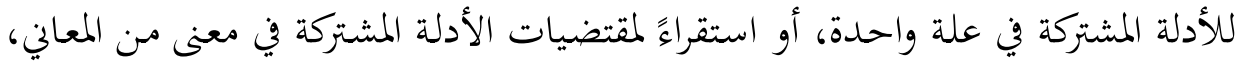

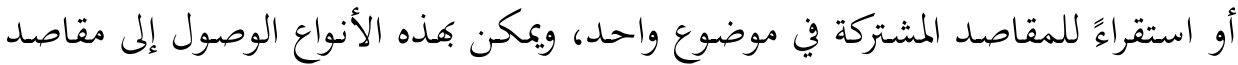

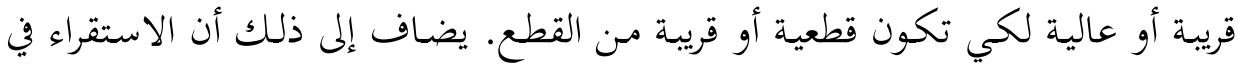

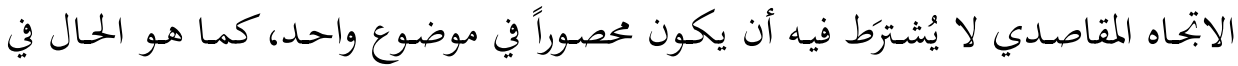

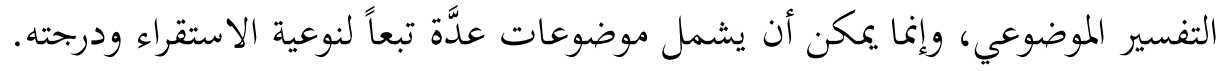
ت. تركيز منهجية التفسير الموضوعي للقرآن في الآيات على ما هو متصل بالموضوع

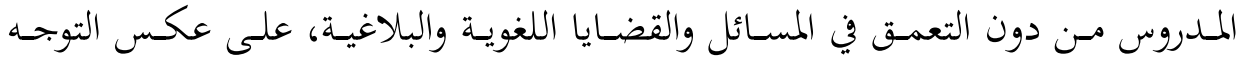

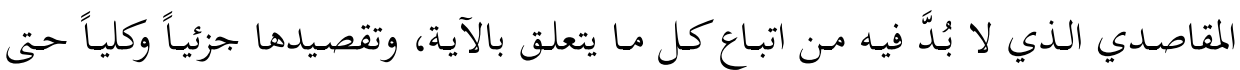
يكون مقصدها مستقراً بمنهجية علمية.

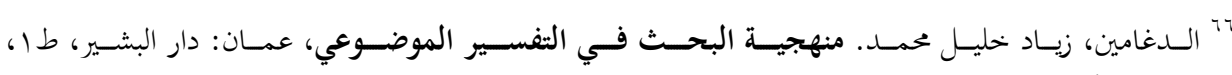
(1)

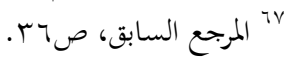


والحقيقة أن هذه الاختلافات لا تعني عدم الالتقاء؛ لأغها ليست اختلافات تضاد، ولهذا يمكن المزاوجة بين التفسير الموضوعي والتوجُّه المقاصدي في الانطلاقتين الآتيتين: الأولى: مراعاة أن يكون اختيار الموضوع المدروس في التفسير الموضوعي من المقاصد المستخلصة بالتفسير المقاصدي، وفي هذا الاختيار خدمة للتوجُّه المقاصدي فئي - منهجية التفسير الموضوعي؛ فهي إمَّا أن تُؤكّد المقصد (موضوع الدراسة) وتُحقِقِه، وإِمَّا أن تُصحِّحه.

- توظيف المقاصد القرآنية باستعمال منهجية التفسير الموضوعي لرؤية مشكلات الواقع على ضوءها، ثم ربطها بالأمور الواقعية.

الثانيـة: جمـع الآيـات والمقاصــ القرآنيـة ذات الصـلة بالموضـوع المــروس، ومعالجــة القضية المطروحة موضوعياً بصورة واقعية، وفي هذا تحقيق للمقاصد القرآنية، واستجلاء

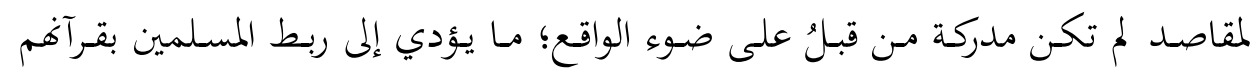

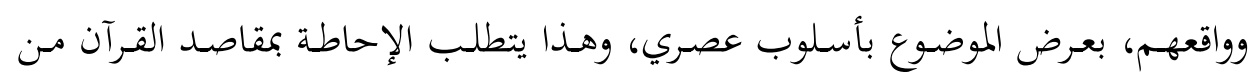

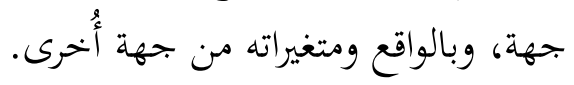

خاتمة:

تصدينا في هذا البحث لمسألة "التفسير المقاصدي للقرآن الكريع"، وقد خرجنا من

جملة البحث بالخلاصة الآتية:

- محاولة بنـاء ابحـاه مقاصدي لا ينفصـل عن الاتحاهـات والمنـاهج التفسيرية، وإنما يتكامل معها، ويُوَّدمها، ويجعلها منطلقاً لبنائه.

- تعدُّد ابتحاهات الباحثين المعاصرين في بيان مفهوم "المقاصد القرآنية" نتيجة عددم

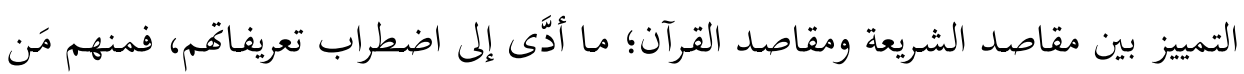

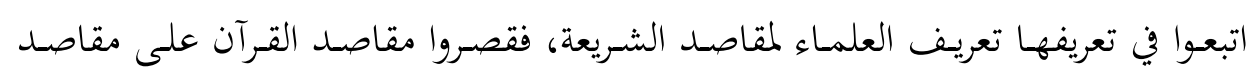

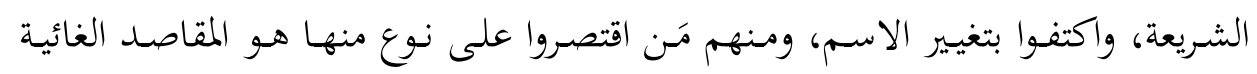




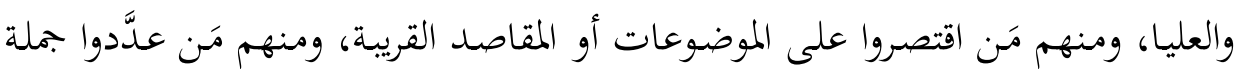
من المقاصد دون اعتماد المسالك العلمية المفضية إلى ذلك؛ ما يشي بخلل منهجي. - العلاقة بين مقاصد القرآن ومقاصد الشريعة هي عموم وخصوص وجهي؛ لذا لا يمكن قصرها عليه.

- المرجح في مفهوم "مقاصد القرآن" هو شموليته لثلاثة مستويات انطلاقاً مَّاّ جاء به

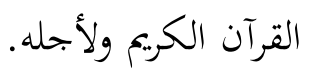

- التفسير المقاصدي هو ابتحاه تفسيري يقوم على الكشف عن المقاصد القرآنية في مستوياتا الثلاثة، ودرجاتا، وترتيبها، وبيان منظومتها البنائية في القرآن الكريع.

- التفسير المقاصدي يستمد مشروعيته من التفسير، وغايته تتمثل في الكشف عن مراد الله له

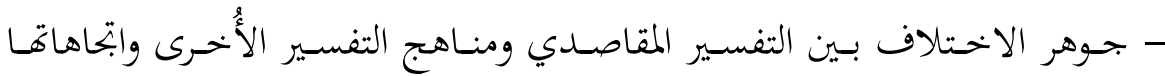

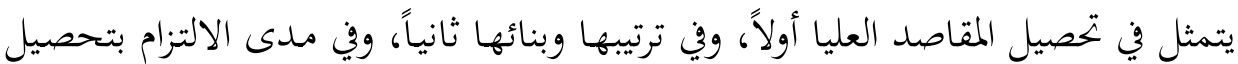
المقاصد الخاصة والكلية ثالثاً.

- الدراسات القرآنية التي أريد فيها أو من بحوثها أن تكشف عن المقاصد القرآنية أو ترتيبها ما تزال محدودة، وتفتقر إلى المنهجية العلمية الموضوعية.

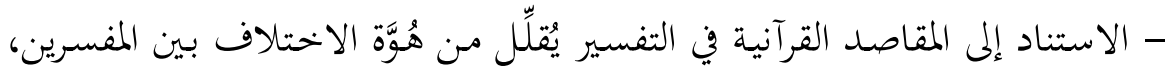

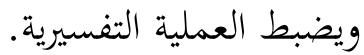

- إن ما يطرأ على العالم من تغيرات في المجالات المختلفة يُظهِِر أهمية هذا النوع من

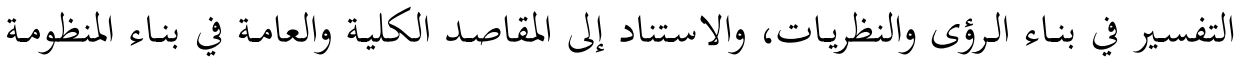
المعرفية الإسلامية المختلفة عن غيرها، ولا سيما في بحال العلوم الإنسانية. - اشتراك هذا الاتحاه مع غيره من الاتجاهات والمناهج في بعض الأدوات التفسيرية،

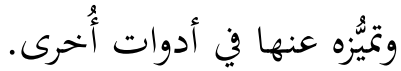


- عدم إغفال هذا الاتجاه الانطلاقتين الرئيستين (من القرآن، ومسن الواقع)، وبذلك تبقى عملية البناء المقاصدي مستمرة.

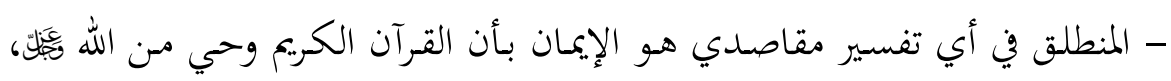
وبصهلاحيته لكل زمان ومكان، وأنه لا يأتيه الباطل مـن بـين يديـه ولا مـن خلفـه، وهـا

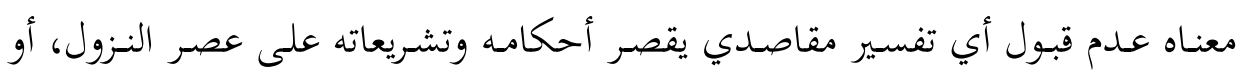
يلغي ما جاءت به آياته وسوره.

وبنـاء على مـا سـبق نقـرر الآتي: إن تأكيــ هــا الابجـاه أو نفيـه عمومـاً لن يـتم إلا بلدراسات مستقبلية، تكشف عمَّا يمكن أن يكون إيجابياً فيه، وما يمكن أن يكون سلبياً، فيتعزَّز الإيجابي، ويُتجاوَز السلبي. أمَّا ما يتصل بالمنظومة الحضارية القرآنية فلا بُدَّ له من عمل مؤسسي تتضافر فيه جهود الباحثين من مختلف التخصصات للكشف عن المقاصد في جميع مستوياها، بدءاً بالقيم الإنسانية، وانطلاقاً من القرآن الكريم والواقع. 